\title{
The genus Habenaria (Orchidaceae) in the Brazilian Amazon
}

\author{
JOÃO A. N. BATISTA ${ }^{1,4}$, JOÃO BATISTA F. DA SILVA² and LUCIANO DE BEM BIANCHETTI ${ }^{3}$
}

(received: August 10, 2006; accepted: February 21, 2008)

\begin{abstract}
The genus Habenaria (Orchidaceae) in the Brazilian Amazon). A survey of Habenaria in the Amazon region in northern Brazil was undertaken. Forty species are recognized for the region. The majority of the species occur in savannah vegetation and the vegetation types with the highest number of species are the inland savannahs on terra firme (19 spp.), the savannahs of Roraima (16 spp.) and the coastal savannahs of Pará and Amapá (15 spp.). Only four species grow in forest and three in the Amazonian caatinga. Nine of these species are restricted in Brazil to the Amazon region, four species from forest formations and three from highlands at the border with Venezuela. Only one species, H. sylvicultrix Lindl. ex Kraenzl., is possibly endemic to northern Brazil. When compared to other regions, the greatest similarity is found with the "cerrado" of the centralwestern region (28 spp. in common) and the Guianas (26 spp.). Only five species are common with the Atlantic Forest. Five species are recorded for the first time or confirmed in Brazil: H. avicula Schltr., $H$. dentifera Schweinf., H. huberi Carnevali \& Morillo, H. lehmanniana Kraenzl. and H. seticauda Lindl. New synonyms are proposed and Habenaria marupaana Schltr. is included under the synonymy of H. amambayensis Schltr., H. platydactyla Kraenzl. under H. schwackei Barb. Rodr., H. mitomorpha Kraenzl. under H. subfiliformis Cogn., and H. pratensis (Salzm. ex Lindl.) Rchb. f. var. parviflora Cogn. under H. spathulifera Cogn.
\end{abstract}

Key words - Amazon, Brazil, Habenaria, Orchidaceae

RESUMO - (O gênero Habenaria (Orchidaceae) na Amazônia Brasileira). Foi realizado um estudo do gênero Habenaria na região da Amazônia brasileira. São registradas 40 espécies para a região. A maioria das espécies ocorre em vegetação de savana e os tipos de vegetação com o maior número de espécies são as savanas interiores de terra firme (19 spp.), as savanas de Roraima (16 spp.) e as savanas do litoral do Pará e Amapá (15 spp.). Apenas quatro espécies são de formações florestais e três das caatingas Amazônicas. Nove espécies são restritas, no Brasil, à região Amazônica incluindo as quatro espécies de formações florestais e três, de áreas altas na região de fronteira com a Venezuela. Apenas uma espécie, H. sylvicultrix, é possivelmente endêmica do norte do Brasil. Quando comparada a outras regiões, a maior similaridade é observada com o cerrado da região centro oeste (28 spp. em comum) e as Guianas (26 spp.). Apenas cinco espécies são comuns com a Mata Atlântica. Cinco espécies são registradas pela primeira vez ou confirmadas para o Brasil: H. avicula Schltr., H. dentifera Schweinf., H. huberi Carnevali \& Morillo, H. lehmanniana Kraenzl. e H. seticauda Lindl. Novos sinônimos são propostos e Habenaria marupaana Schltr. é incluída sob a sinonímia de H. amambayensis Schltr., H. platydactyla Kraenzl. sob H. schwackei Barb. Rodr., H. mitomorpha Kraenzl. sob H. subfiliformis Cogn.e H. pratensis (Salzm. ex Lindl.) Rchb. f. var. parviflora Cogn. sob H. spathulifera Cogn.

Palavras-chave - Amazônia, Brasil, Habenaria, Orchidaceae

\section{Introduction}

Habenaria has a temperate and pantropical distribution and the main centers of diversity are in Brazil, southern and central Africa, and East Asia (Kurzweil \& Weber 1992). The genus accounts for about 600 species (Pridgeon et al. 2001) of which 165-170 are known from Brazil (Hoehne 1940, Pabst \& Dungs 1975). The genus is typical of open grasslands and the main centers of

1. Universidade Federal de Minas Gerais, Departamento de Botânica, Av. Antônio Carlos 6627, Pampulha, Caixa Postal 486, 31270-910 Belo Horizonte, MG, Brazil.

2. Museu Paraense Emílio Goeldi, Departamento de Botânica, Av. Magalhães Barata 376, 66040-170 Belém, PA, Brazil.

3. Embrapa Recursos Genéticos e Biotecnologia, Parque Estação Biológica, Final Av. W5 Norte, Caixa Postal 02372, 70770-901 Brasília, DF, Brazil.

4. Corresponding author: janb@icb.ufmg.br diversity in Brazil are the cerrado (savannah vegetation) and campos rupestres (rocky fields) vegetation of the centralwestern and southeastern regions. In the Distrito Federal alone $\left(5,783 \mathrm{~km}^{2}\right)$, located in the central region of the cerrado vegetation of central Brazil, there are 77 taxons of Habenaria (Batista \& Bianchetti 2003).

Until very recently there were no specific works about the Orchidaceae of the Brazilian Amazon, and the knowledge of the Orchids of that region was restricted to the major taxonomic works of the Brazilian Orchidaceae. Cogniaux (1893) in Flora Brasiliensis reported six species of Habenaria for northern Brazil, Hoehne (1940) in Flora Brasilica recorded 20 species and Pabst \& Dungs (1975), in Orchidaceae Brasilenses, raised that number to 30 Habenaria species. In the most recent floristic surveys of the Orchidaceae of the Brazilian Amazon, Silva et al. (1995) based on their own collections recorded 
seven Habenaria species and Silva \& Silva (2004) reported 33 species for the region. However, in the list of Silva \& Silva (2004), seven species are now considered synonyms of other species in the same list. In between, several new species were described for the region (Schlechter 1914, 1925a, b, Hoehne 1937, Pabst 1955) and there were a few other reports of Habenaria species included in regional surveys such as the Orchidaceae from the states of Amapá (Pabst 1967) and Pará (IlkiuBorges \& Cardoso 1996), Brazil's highlands at the border with Venezuela at Serra da Neblina (Dunsterville 1972), Serra dos Carajás (Silveira et al. 1995), Serra das Andorinhas (Atzingen et al. 1996) and the orchids of the IAN Herbarium (Pabst 1955, 1962).

As a contribution to the taxonomy and geographical distribution of the genus Habenaria and to the flora of the Brazilian Amazon we present here a survey of the genus Habenaria in the Amazon region of Brazil.

\section{Material and methods}

The area covered by the present study includes basically the states of northern Brazil (Acre, Amapá, Amazonas, Pará, Rondônia, Roraima) and northern Mato Grosso. Northern Tocantins and western Maranhão are also included, but Habenaria collections available from these areas are not significant. Other parts of Mato Grosso, Maranhão and Tocantins belong to legal Amazonia, but were not included in this survey because they are more related to other biomes than to the Amazon forest. Definition of the Amazonian vegetation types follows Pires \& Prance (1985).

The survey was based on collections made by the authors and on dried specimens. Species recorded in the literature but not examined were not included. Material from the following herbaria was examined: AMES, CEN, EAC, ESA, HB, HRB, HRCB, IAC, IAN, INPA, MBM, MG, MPU, NY, OXF, R, RB, SP, SPF, and UB. The species were identified by comparing them to the original descriptions and, when available, with the type material. Images of type material from the following herbaria were seen: BM, BR, K, M, NY, $\mathrm{P}, \mathrm{RENZ}, \mathrm{S}, \mathrm{U}, \mathrm{US}$ and $\mathrm{W}$. The main taxonomic works consulted were Lindley (1830-1840, 1843), Barbosa-Rodrigues (1877, 1882), Kraenzlin (1892), Cogniaux (1893), and Hoehne (1937). In the list of synonyms, only those relevant to the region were included. Illustrations are based primarily on the material from Northern Brazil, and in a few cases, when there were no well conserved flowers for sketches, the material from the "cerrado" of central Brazil was used.

\section{Results and discussion}

Floristics - Forty species of Habenaria are recorded here for the Amazon region of Brazil. This represents an addition of about 14 species when compared to previous reports (Hoehne 1940, Pabst \& Dungs 1975, Silva \& Silva 2004). Among the Orchidaceae, the genus is probably the forth in number of species in the region, surpassed only by Catasetum (57 species), Pleurothallis s.l. (46 spp.), Maxillaria (44 spp.) and possibly Epidendrum (40 spp.). This high number of Habenaria species is somehow unexpected as the genus is typical of open grasslands, a type of vegetation which corresponds only to a small part of the Amazonian vegetation. This result is probably due to the floristic importance of the savannah vegetation physiognomies to the Brazilian Amazon flora. Accordingly, the states with the highest number of species are those with the largest extensions of savannah vegetation. An exception is the state of Maranhão, in which large extensions of savannahs are unfortunately poorly collected. The number of Habenaria species per state is: 25 for Pará, 16 for Roraima, 10 for Amazonas, nine for northern Mato Grosso, eight for Amapá, four for Rondônia, two for western Maranhão and one for Acre.

Five species are recorded for the first time or confirmed for Brazil: H. avicula, H. dentifera, H. huberi, $H$. lehmanniana, and $H$. seticauda. The first two are forest and Amazonian "caatinga" species from northern Mato Grosso and Amazonas, H. huberi is recorded from Rondônia and H. lehmanniana and H. seticauda from the Serra of Pacaraima in Roraima, at the border with Venezuela.

Sixteen species of Habenaria were described from northern Brazil. Of these, five are accepted here $(H$. depressifolia, $H$. longipedicellata, $H$. quadrata, H. sprucei, and $H$. sylvicultrix), ten are considered synonyms $(H$. amazonica Schltr., H. culmiformis Schltr., H. dentirostris Pabst, H. duckeana Schltr., H. georgii Schltr., H. kuhlmannii Schltr., H. leaoana Schltr., H. marupaana Schltr., H. staminodiata Schltr., and $H$. viridiaurea Lindl. ex Kraenzl.) and one is an obscure taxon ( $H$. achroantha Schltr.). Only H. sylvicultrix is possibly restricted to the Brazilian Amazon, but this hypothesis needs further investigation as $H$. dusenii Schltr., a species widespread in central, south and southeastern Brazil, is very similar and probably conspecific.

In terms of sampling there are 4.9 collections per species (196 collections for 40 species) for the region. When compared to some Habenaria species-rich regions that have been well sampled, like the Distrito Federal with 11.1 collections per spp., the value for northern Brazil is low, but similar to other regions with an intermediate number of species and that are moderately surveyed, such as the state of Bahia (5.8 collections per spp.). The 
species with the highest number of collections are $H$. trifida, with 26 collections, followed by $H$. longipedicellata (14 collections) and $H$. spathulifera (12 collections). The first two species can colonize disturbed and man made habitats, like roadsides and pastures, and this may explain the higher number of collections. Twenty one species $(52 \%)$ are only known by one to three collections. Comparison with other areas - When compared to the Habenaria species composition of other regions, 28 (70\%) of the species from the Brazilian Amazon occur in the "cerrado" of the centralwestern region, $26(65 \%)$ occur in the Guianas and 17 (42\%) in the Venezuelan Guayana (comparison to the lists of Renz (1992) and Carnevali et al. (2003), respectively). The Atlantic forest has only five Habenaria species (12.5\%) in common with the Amazon, four of which are widespread species that also occur in other Brazilian biomes. None of the Habenaria forest species typical of the Atlantic forest, such as H. josephensis Barb. Rodr., H. nemorosa Barb. Rodr. and H. umbraticola Barb. Rodr. occur in the
Amazon region and none of the Habenaria forest species from the Amazon region such as $H$. alterosula Snuvenrink \& Westra and $H$. dentifera Schweinf. occur in the Atlantic forest. In addition, other forest species with broad distribution such as $H$. cryptophila Barb. Rodr., H. distans Griseb. and H. glaucophylla Barb. Rodr. have not been recorded for the Amazon region of Brazil.

Distribution of the species per vegetation type - The majority (32 spp. $=80 \%$ ) of the Habenaria species in northern Brazil occur in savannah vegetations (table 1). The vegetation types with the highest number of species are the inland savannahs on terra firme (19 spp.), the savannahs of Roraima (16 spp.), and the coastal savannahs of Pará and Amapá (15 spp.). Six species are known from the savannahs on rocky soil ("campo rupestre") and four from the inundated savannah of lower Amazon. One species, $H$. roraimensis, is restricted to the high altitude fields of the mountain range at the borders of Brazil with Venezuela and Guyana.

Table 1. Distribution of the Habenaria species per vegetation type. (T.F. = savannahs on "terra firme"; S.R. = savannahs of Roraima; C.S. = coastal savannahs of Pará and Amapá; C.R. = "campo rupestre"; I.S. = inundated savannah of lower Amazonia; For. = "terra firme" forests; Caa. = "caatinga"; Aqu. = aquatic).

\begin{tabular}{|c|c|c|c|c|c|c|c|c|}
\hline & \multicolumn{5}{|c|}{ Savannahs } & \multirow[t]{2}{*}{ For. } & \multirow[t]{2}{*}{ Caa. } & \multirow[t]{2}{*}{ Aqu. } \\
\hline & T.F. & S.R. & C.S. & C.R. & I.S. & & & \\
\hline H. alterosula Snuvenrink \& Westra & & & & & & $\mathrm{x}$ & & \\
\hline H. amambayensis Schltr. & $\mathrm{x}$ & $\mathrm{x}$ & $\mathrm{x}$ & & & & & \\
\hline H. aricaensis Hoehne & $\mathrm{x}$ & & & & & & & \\
\hline H. armata Rchb. f. & $\mathrm{x}$ & $\mathrm{x}$ & & & & & & \\
\hline H. avicula Schltr. & & & & & & & $\mathrm{x}$ & \\
\hline \multicolumn{9}{|l|}{ H. ayangannensis Renz } \\
\hline H. candolleana Cogn. & $\mathrm{x}$ & & & $\mathrm{x}$ & & & & \\
\hline H. dentifera Schweinf. & & & & & & $\mathrm{x}$ & $\mathrm{x}$ & \\
\hline H. depressifolia Hoehne & $\mathrm{x}$ & & $\mathrm{x}$ & & & & & \\
\hline H. glazioviana Kraenzl. ex Cogn. & $\mathrm{x}$ & & & $\mathrm{x}$ & & & & \\
\hline H. goyazensis Cogn. & & & $\mathrm{x}$ & & & & & \\
\hline H. hamata Barb. Rodr. & $\mathrm{x}$ & & $\mathrm{x}$ & & & & $\mathrm{x}$ & \\
\hline H. heptadactyla Rchb. f. & $\mathrm{x}$ & $\mathrm{x}$ & & & $\mathrm{x}$ & & & \\
\hline H. hexaptera Lindl. & $\mathrm{x}$ & & & & & & & \\
\hline H. huberi Carnevali \& Morillo & $\mathrm{x}$ & & & & & & & \\
\hline H. aff. josephensis Barb. Rodr. & & & & & & $\mathrm{x}$ & & \\
\hline H. lehmanniana Kraenzl. & & $\mathrm{x}$ & & & & & & \\
\hline H. leprieuri Rchb. f. & $\mathrm{x}$ & $\mathrm{x}$ & $\mathrm{x}$ & & & & & \\
\hline H. longicauda Hook. & & & & & & & & $\mathrm{x}$ \\
\hline H. longipedicellata Hoehne & $\mathrm{x}$ & & $\mathrm{x}$ & & & & & \\
\hline H. ludibundiciliata J. A. N. Bat. \& Bianch. & $\mathrm{x}$ & $\mathrm{x}$ & $\mathrm{x}$ & $\mathrm{x}$ & & & & \\
\hline H. macilenta (Lindl.) Rchb. f. & & $\mathrm{x}$ & $\mathrm{x}$ & & & & & \\
\hline H. nabucoi Ruschi & & & & & & & & $\mathrm{x}$ \\
\hline H. aff. nuda Lindl. & & & & $\mathrm{x}$ & & & & \\
\hline
\end{tabular}


continuation

\begin{tabular}{|c|c|c|c|c|c|c|c|c|}
\hline & \multicolumn{5}{|c|}{ Savannahs } & \multirow[t]{2}{*}{ For. } & \multirow[t]{2}{*}{ Caa. } & \multirow[t]{2}{*}{ Aqu. } \\
\hline & T.F. & S.R. & C.S. & C.R. & I.S. & & & \\
\hline H. obtusa Lindl. & $\mathrm{x}$ & & $\mathrm{x}$ & & & & & \\
\hline H. orchiocalcar Hoehne & $\mathrm{x}$ & & & $\mathrm{x}$ & & & & \\
\hline H. parviflora Lindl. & & $\mathrm{x}$ & & & & & & \\
\hline H. petalodes Lindl. & & & $\mathrm{x}$ & & & & & \\
\hline H. quadrata Lindl. & & & & & & $\mathrm{x}$ & & \\
\hline H. repens Nuttall & & & & & & & & $\mathrm{x}$ \\
\hline H. roraimensis Rolfe & & $\mathrm{x}$ & & & & & & \\
\hline H. schwackei Barb. Rodr. & & $\mathrm{x}$ & $\mathrm{x}$ & & & & & \\
\hline H. secundiflora Barb. Rodr. & $\mathrm{x}$ & $\mathrm{x}$ & & & & & & \\
\hline H. seticauda Lindl. & & $\mathrm{x}$ & & & & & & \\
\hline H. spathulifera Cogn. & $\mathrm{x}$ & $\mathrm{x}$ & $\mathrm{x}$ & & $\mathrm{x}$ & & & \\
\hline H. sprucei Cogn. & $\mathrm{x}$ & $\mathrm{x}$ & $\mathrm{x}$ & & $\mathrm{x}$ & & & \\
\hline H. subfiliformis Cogn. & & $\mathrm{x}$ & $\mathrm{x}$ & & & & & \\
\hline H. sylvicultrix Lindl. ex Kraenzl. & & & & & $\mathrm{x}$ & & & \\
\hline H. trifida Kunth & $\mathrm{x}$ & $\mathrm{x}$ & $\mathrm{x}$ & & & & & \\
\hline H. aff. warmingii Rchb. f. \& Warm. & & & & $\mathrm{x}$ & & & & \\
\hline Total & 19 & 16 & 15 & 6 & 4 & 4 & 3 & 3 \\
\hline
\end{tabular}

Four species are typically from forest, including both terra firme and inundated forests ("várzeas" and "igapós"). Some additional species, such as $H$. petalodes, $H$. longipedicellata and $H$. hexaptera can occasionally grow at the border or inside forests, but all are more frequent and typical of open vegetation. The proportion of Habenaria forest species in the
Amazon (10\%) is higher than the proportion of the genus in Brazil, where only $5 \%-6 \%$ of the total number of species are from forests. Only three species $(7.5 \%)$ are known from the Amazonian caatingas or campinaranas. Lastly, three species are typically aquatic or semi aquatic, growing in water at the margins of streams, lakes and rivers.

Key to the Habenaria species from the Brazilian Amazon

1. Leaves basal, orbicular, fleshy, reticulate, adpressed to ground

H. depressifolia

1. Leaves distributed along the stem, oblong, lanceolate or linear, membranaceous or papery.

2. Plants aquatic; spur $\geq 10 \mathrm{~cm}$ long; stigmas $6-12 \mathrm{~mm}$ long, margins involute.

3. Flowers light green; dorsal sepal 13-17 mm long; lip segments and lateral sepals reflexed in fully opened flowers, forming a right angle with the dorsal sepal; midlobe of rostelum 3.5-4 mm high, completely enclosed between the anthers; spur 13-20(-25) cm long, acuminate, (apex ca. $1 \mathrm{~mm}$ wide)

H. longicauda

3. Flowers white; dorsal sepal 20-23 mm long; lip segments and lateral sepals not reflexed; midlobe of rostellum $8-9 \mathrm{~mm}$ high, partially projected beyond the anthers; spur 10-15 cm long, clavate, thickened towards the apical part (apex 2-4 mm wide) H. nabucoi

2. Plants terrestrial (except $H$. repens), but many from humid places and marshes; spur $<10 \mathrm{~cm}$ long (except $H$. aricaensis and $H$. hamata); stigmas $0.5-4 \mathrm{~mm}$ long, margins not involute.

4. Petals and lip yellow or orange; segments of the lip spatulate, $2-5 \mathrm{~mm}$ wide (occasionally linear in H. spathulifera); midlobe of rostellum conspicuous, projected beyond the anthers.

5. Pedicellate ovary $1.6-2.5 \mathrm{~cm}$ long; flowers bright yellow H. spathulifera

5. Pedicellate ovary 3-5 cm long; flowers light yellow or orange. 
6. Flowers light yellow; lip midlobe very broad, roundish, cordate or obreniform, 10-22 mm wide

H. glazioviana

6. Flowers orange; lip midlobe oblong, ca. $5 \mathrm{~mm}$ wide H. huberi

4. Petals and lip usually green or white, rarely pure yellow; lateral segments of the lip usually linear, not spatulate (except $H$. schwackei), 0.3-1.5 mm wide; midlobe of rostellum variable in size, enclosed between or project beyond the anthers.

7. Pedicel $1.5-9 \mathrm{~cm}$ long, the same size or longer than the ovary; midlobe of rostellum prominent, apex projected beyond the anthers.

8. Spur small, ovoid, scrotiform, 3-3.5 mm long

H. orchiocalcar

8. Spur long, linear to clavate, $2.5-9.5 \mathrm{~cm}$ long.

9. Dorsal sepal 10-18 mm long; petals and lip completely white or yellow.

10. Dorsal sepal 10-12 mm long; lateral sepals $2.5-3 \mathrm{~mm}$ broad; petals and lip yellow; lip undivided base conspicuous, 3-4 mm long; rostellum midlobe with acute apex

H. macilenta

10. Dorsal sepal (8-)10-15(-19) mm long; lateral sepals (4-)4.5-6(-7) mm broad; petals and lip white; lip undivided base short, 1-2 mm long; rostellum midlobe with truncate apex H. trifida

9. Dorsal sepal 5-7 mm long; petals and lip green-white.

11. Leaves adpressed to the stem; lateral segment of the petal 1.5-2 times as long as the posterior segment

H. sylvicultrix

11. Leaves spreading from the stem; lateral segment of the petal the same size or slightly longer than the posterior segment.

12. Dorsal sepal 6-7 mm long; lateral segments of the petals and lip about the same size as the posterior petal and midlobe of lip; spur thickened towards the apical part, often curved forwards; apex of midlobe of rostellum broad, truncate

H. lehmanniana

12. Dorsal sepal 4-6 mm long; lateral segments of the petals and lip usually longer than the posterior petal and midlobe of lip; spur narrowly cylindric throughout, apex mostly hidden among the bracts; apex of midlobe of rostellum narrow, acute

H. longipedicellata

7. Pedicel $0.1-1.3 \mathrm{~cm}$ long, shorter than the ovary; midlobe of rostellum not prominent, completely enclosed between the anthers.

13. Leaves conspicuous, only the basal part adpressed to the stem, the blade spread, broad, linear, lanceolate or oblong.

14. Petals and lip simple; lateral segments, when present, obscure or short.

15. Plants mainly from savannahs; flowers green-white; dorsal sepal

7-30 x 6-15 mm; spur $2.6-12 \mathrm{~cm}$ long.

16. Flower segments elongated; dorsal sepal ca. $3 \mathrm{~cm}$ long; petals and lip with a conspicuous basal segment, ca. 4-6 mm long .... H. aricaensis

16. Flower segments not elongated; dorsal sepal $0.7-1.6 \mathrm{~cm}$ long; petals and lip simple or with an obscure basal segment, ca. $1 \mathrm{~mm}$ long.

17. Bracts not imbricate, not covering the rachis; dorsal sepal 1.2-1.6 cm long; lip 2.5-3.6 cm long; spur sinuous or hook shaped, free, not enclosed between the bracts, $9.5-12 \mathrm{~cm}$ long H. hamata

17. Bracts imbricate, usually covering the rachis; dorsal sepal 0.7-1.0 mm long; lip 1.0-1.8 cm long; spur straight, usually enclosed between the bracts, $2.6-9.5 \mathrm{~cm}$.

18. Spur (2.6-)3.5-4.5(-5.5) cm long H. obtusa

18. Spur 8-9.5 cm long 
15. Plants mainly from forests or "caatinga" (except $H$. hexaptera and $H$. petalodes); flowers mostly green; dorsal sepal 4.5-11 x 3.5-9 mm; spur $1.0-3.5 \mathrm{~cm}$ long.

19. Lateral segment of the petals conspicuous, tooth like, $1 / 2$ the size of the posterior segment, ca. 2 x $1 \mathrm{~mm}$, apex obtuse; posterior segment of the petal with a conspicuous tridentate apex; spur 3-3.5 cm long. .....

H. dentifera

19. Lateral segment of the petals absent or little developed, $1 / 4$ to $1 / 8$ the size of the posterior segment, when present with an acute apex; apex of the posterior segment of the petal obtuse, truncate, acute or obscurely tridentate; spur $1-2.5 \mathrm{~cm}$ long.

20. Petals oblong-spatulate; apex truncate, $4-7 \mathrm{~mm}$ wide

H. petalodes

20. Petals oblong, linear or falcate, not spatulate; apex acute or, when truncate, $1-1.5 \mathrm{~mm}$ wide.

21. Anther canals $2 \mathrm{~mm}$ long.

22. Leaves concentrated on the middle of the stem; petals and lip with lateral segments 1-2 mm long; apex of the petal posterior segment acute H. avicula

22. Leaves distributed along the stem; petals and lip simple or with an inconspicuous basal segment ca. $0.5 \mathrm{~mm}$ long; apex of the petal posterior segment truncate

H. quadrata

21. Anther canals ca. $1 \mathrm{~mm}$ long.

23. Dorsal sepal 7-9 x 5-7 mm, conspicuously apiculate; posterior segment of the petal 6-8 mm long, spur 1-2 mm wide H. hexaptera

23. Dorsal sepal 4-4.5 x 3-4 mm, obscurely apiculate; posterior segment of the petal $4 \mathrm{~mm}$ long; spur $0.5 \mathrm{~mm}$ wide.... H. aff. josephensis

14. Petals bipartite; lip tripartite; lateral segments little shorter, the same size or longer than the posterior petal and midlobe of lip.

24. Lateral segments of the petals and lip slightly shorter, the same size or

little longer than the posterior petal segment and midlobe of lip.

25. Plants from inside forest; leaves in rosette at the middle of the stem ..... H. alterosula

25. Plants from open areas or, at most in the border of forests; leaves basal or distributed along the stem.

26. Dorsal sepal 3-4.5 mm long; spur 0.6-1.0 cm long.

27. Plants aquatic; dorsal sepal 3-4.5 mm long; lateral sepals 2-3 mm wide; lateral segments of the petals and lip little longer than the petal posterior segment and lip midlobe H. repens

27. Plants from water saturate areas, but not aquatic; dorsal sepal 3-3.5 mm long; lateral sepals 1-1.5 mm wide; lateral segments of the petals and lip shorter than the petal posterior segment and lip midlobe

H. parviflora

26. Dorsal sepal 6-7 mm long; spur 3.5-4.5 cm long.

28. Leaves concentrated in the stem base; inflorescence lax, 2-4-flowered; sepals green, petals and lip white; lateral segments of the petals and lip shorter than the petal posterior segment and lip midlobe; spur little longer than the pedicellate ovary ..... H. candolleana

28. Leaves spread along the stem; inflorescence congest, 6-30-flowered; flowers mostly green; lateral segments of the petals and lip little longer than the petal posterior segment and lip midlobe; spur twice as long as the pedicellate ovary .... H. goyazensis 
24. Lateral segments of the petals and lip 1.5-2 times longer than the posterior petal segment and midlobe of lip.

29. Plants $15-30 \mathrm{~cm}$ tall; larger leaves usually concentrated in the stem base; dorsal sepal 4-5 $\mathrm{mm}$ long; lateral segment of the petal ca.

$8 \mathrm{~mm}$ long; spur ca. $6 \mathrm{~mm}$ long H. armata

29. Plants $24-90 \mathrm{~cm}$ tall; larger leaves distributed along the stem; dorsal sepal 6-13 mm long, lateral segment of the petal ca. 13-25 mm long; spur 14-22 mm long.

30. Dorsal sepal 6-7 x $5 \mathrm{~mm}$, petal lateral segment ca. $13 \mathrm{~mm}$ long, spur ca. $14 \mathrm{~mm}$ long H. amambayensis

30. Dorsal sepal 11-13 x 6-7 mm, petal lateral segment $22-25 \mathrm{~mm}$ long, spur 20-22 mm long H. aff. warmingii

13. Leaves usually inconspicuous, mostly adpressed to the stem, linear or filiform, frequently grasslike (except $H$. aff. nuda), narrow.

31. Dorsal sepal 3-4 mm long; midlobe of lip 2-4(-6) mm long.

32. Flowers usually bright yellow, rarely green; inflorescence congest, densely-flowered. H. heptadactyla

32. Flowers green; inflorescence lax, loosely-flowered.

33. Lateral sepals conspicuously aristate; lateral segments of the petals and lip usually ciliate H. ludibundiciliata

33. Lateral sepals not or obscurely aristate; lateral segments of the petals and lip never ciliate.

34. Bracts shorter than the pedicellate ovary; flowers spreading from the rachis

H. ayangannensis

34. Bracts equaling or exceeding the pedicellate ovary; flowers not spread, main axis parallel to the rachis.

35. Lateral sepals linear to narrowly lanceolate; lip midlobe $1 \mathrm{~mm}$ wide; spur 8-12 $\mathrm{mm}$ long. H. leprieuri

35. Lateral sepals lanceolate-ovate to broadly lanceolate; lip midlobe $0.5 \mathrm{~mm}$ wide; spur 5-6.5 mm long

H. subfiliformis

31. Dorsal sepal 4-11 mm long; midlobe of lip (4-)5-12 mm long.

36. Pedicel 5-9 mm long; sepals green; petals and lip white H. schwackei

36. Pedicel 1-2 mm long; sepals, petals and lip green or greenish-yellow.

37. Petal lateral segment from a reduced tooth like projection to ca.

$3 / 4$ the size of the posterior segment, $1-5 \mathrm{~mm}$ long H. roraimensis

37. Petal lateral segment 6-11 mm long.

38. Dorsal sepal lanceolate to broadly lanceolate, 5-6 x 3-4 mm; petals entire for about $2 \mathrm{~mm}$ from the base and then divided above. H. secundiflora

38. Dorsal sepal orbicular to roundish, 6-9 x 5.5-8 mm; petals divided near the base.

39. Leaves linear, not grasslike, $4-8 \mathrm{~mm}$ wide; dorsal sepal 7-9 x 6.5-8 mm; petal posterior segment connivent with the dorsal sepal; lip lateral segments slightly longer and narrower than the midlobe H. aff. $n u d a$

39. Leaves filiform, grasslike, 3-4 mm wide; dorsal sepal ca. $6 \times 5.5 \mathrm{~mm}$; petal posterior segment spreading, not connivent with the dorsal sepal; lip lateral segments and midlobe of approximately the same length and width ...... 
1. Habenaria alterosula Snuvenrink \& Westra, Acta. Bot. Neerl. 30(3):235. 1981. Type: SURINAME. Lelygebergte, 29-V-1976, M. \& P. Teunissen 1635 (Holotype BBS).

Figure 1A-D

Specimens examined: BRAZIL. PARÁ: Monte Alegre, 17-VII-1981, J. Jangoux \& B.G.S. Ribeiro 1451 (MG).

Distribution: Brazil (PA), French Guiana and Surinam. Illustrations: Snuverink \& Westra (1983, Figure 2), Werkhoven (1986, p.141).

This species is similar and apparently closely related to $H$. avicula. The main difference is in the length of the lateral segments of the lip (about $5 \mathrm{~mm}$ in H. alterosula vs. 1-2 mm in H. avicula). The flower depicted in Lindley's original drawings of $H$. abortiens Lindl., a poorly know species described previously from Peru, is remarkably similar to $H$. alterosula and it is possible that the two species may be conspecific. In the only collection of $H$. alterosula known from Brazil the species was collected in a terra firme forest. Flowers are recorded as green.

2. Habenaria amambayensis Schltr., Repert. Spec. Nov. Regni Veg. 16: 353. 1920. Type: PARAGUAY. Sierra de Amambay, II-1913, E. Hassler 10969 (Isotypes BM, MPU, NY, S; drawing and fragment of the isotype RENZ).

= Habenaria marupaana Schltr., Bot. Centralbl. Beih. 42(2):73. 1925. Type: BRAZIL. Rio Branco, Serra do Marupá, I-1913, J.G. Kuhlmann 776 (Holotype B, destroyed; Isotypes AMES, RB, SP) syn. nov.

\section{Figure 1E-F}

Selected specimens examined: BRAZIL. AmAPÁ: Macapá, 9-VI-1981, J.B. Rabelo 1286 (MG); PARÁ: Ilha de Marajó, 1877, Jobert 122 (R); RondônIA: Alta Floresta, 11-VII-1997, L.C.B. Lobato et al. 1727 (MG); Roraima: Boa Vista, 12-X-1991, J.B.F. da Silva 247 (MG), Pacaraima village, 18-VI-1999, J.B.F. da Silva 828 (MG), Amajari, 8-X-2005, J.A.N. Batista 1592 (BHCB).

Distribution: Brazil (AP, MS, MT, PA, RO, RR), French Guiana, Guyana and Paraguay.

Illustrations: Mansfeld (1930, Tafel 1, Figure 1; Tafel 4, Figure 15), Silva \& Silva (2004, p.250 as $H$. schomburgkii).

This species is similar to $H$. repens but differs by the size of the flowers and length of the lateral segments of the petals and lip (about 12-15 $\mathrm{mm}$ in H. amambayensis vs. ca. 4-7 $\mathrm{mm}$ in $H$. repens). In the type material and original description of $H$. marupaana, plants and inflorescences are shorter and the lateral segments of the petals and lip less developed than in H. amambayensis. However, these caracters are somewhat variable in $H$. amambayensis and the two species agree well in all of the other details of flower morphology. Habenaria amambayensis is also similar to H. schomburgkii and the exact distinction between the two species is not completely clear. The flowers of $H$. amambayensis are completely green and the species is typical of marshes and permanently humid places, usually with water over the soil.

3. Habenaria aricaensis Hoehne, Comm. Linhas Teleg. Estrateg. Matto Grosso Annexo 5, Bot. 5: 30, t.84. 1915. Type: BRAZIL. Mato Grosso: Cuyabá, III-1911, F.C. Hoehne 4092 (Holotype R).

Figure 1G-H

Selected specimens examined: BRAZIL. RondônIA: Rio Guaporé, 15-VI-1952, G.A. Black \& E. Cordeiro 52-15016 (IAN); Tocantins: Araguaçu, 16-II-1997, J.A.N. Batista et al. 682 (CEN).

Distribution: Brazil (MT, RO, TO).

Illustration: Pabst \& Dungs (1975, Figure 7).

This species is similar to $H$. hamata but distinct by the short lateral segments of the petals and lip (ca. 4-6 mm long in $H$. aricaensis vs. absent or at most obscure in H. hamata) and the completely white flowers (vs. a green lip and green and white sepals). Habenaria aricaensis is an uncommon species, restricted to the Brazilian "Pantanal" and the northern part of the "cerrado" biome, where it borders and occasionally enters the southwestern part of the Amazon region. The species grows in water or in very humid places.

4. Habenaria armata Rchb. f., Bonplandia. 2(2):10. 1854. Type: VENEZUELA. CARACAs: Wagener s.n. (Holotype W; photocopy, drawing and fragment of the holotype RENZ).

Figure 1I

Specimens examined: BRAZIL. PARÁ: Paru do Oeste River, 16-III-1962, D.C. Fittkau s.n. (INPA12768); Roraima: Boa Vista, 19-VI-1999, J.B.F. da Silva 846 (MG). VENEZUELA. Bolívar: Gran Sabana, Mount Roraima, 22-VIII-1997, R.S. Oliveira 236 (CEN).

Distribution: Brazil (DF, GO, MG, PA, PR, RR, SP), Colombia, Guyana, Surinam and Venezuela.

Illustrations: Foldats (1969, Figure 15), Dunsterville \& Garay (1979, Figure 337), Snuverink \& Westra (1983, Figure 6) all as $H$. entomantha.

This species is similar in flower morphology to $H$. amambayensis and $H$. aff. warmingii, characterized by 

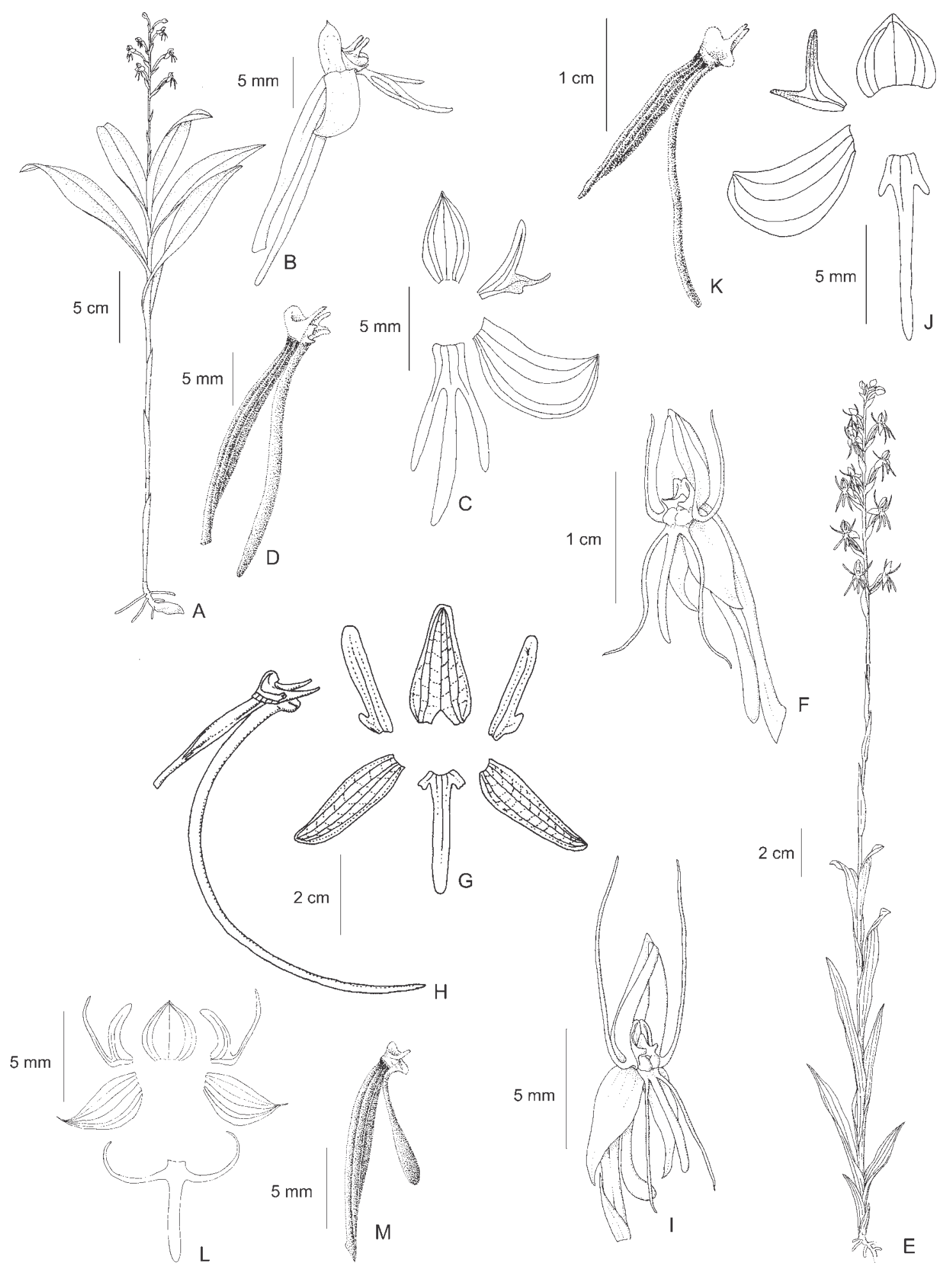
the lateral segments of the petals and lip, which are distinctly longer than the corresponding petal posterior segment and lip midlobe. However, $H$. armata is distinct by smaller plants (about $15-30 \mathrm{~cm}$ tall in $H$. armata vs. $24-76 \mathrm{~cm}$ tall in $H$. amambayensis and around $90 \mathrm{~cm}$ tall in $H$. aff. warmingii), the larger leaves concentrated on the lower part of the stem (vs. the larger leaves concentrated in the middle of the stem in H. amambayensis and $H$. aff. warmingii) and smaller flowers (dorsal sepal about 4-5 x $3 \mathrm{~mm}$ vs. 6-7 x $5 \mathrm{~mm}$ in $H$. amambayensis and $11-13 \times 6-7 \mathrm{~mm}$ in $H$. aff. warmingii). Flowers are completely green and the species is typical of dry or at most seasonally humid places.

5. Habenaria avicula Schltr., Repert. Spec. Nov. Regni Veg. 17: 138. 1921. Type: PANAMA. XII-1900, W. Joseph s.n. (Holotype B, destroyed; no isotype located) n.v.

Figure 1J-K

Specimens examined: BRAZIL. AmAzonas: basin of Rio Negro, Camanaus, 31-X-1971, G.T. Prance et al. 15907 (HB, INPA, NY).

Distribution: Brazil (AM), Colombia, Panama, Peru and Venezuela.

This species is similar to H. leptoceras Hook., found in the Atlantic forest and "restingas" in the states of Rio de Janeiro, Espirito Santo and Bahia in southeastern Brazil. However, in H. avicula, similarly to H. alterosula, the leaves are concentrated on the middle or upper part of the stem and the lateral segments of the lip range from about $1 \mathrm{~mm}$ long to almost absent. In H. leptoceras the leaves are better distributed along the stem or concentrated on the lower part, and the lateral segments of the lip are (2-)3-4 mm long. The only collection of $H$. avicula known from Brazil was collected in a "caatinga" on white sand, a vegetation similar to the coast sandy "restingas", where H. leptoceras is typically found. Flowers are recorded as green and white.

6. Habenaria ayangannensis Renz, Candollea 47(2): 490, figure 1. 1992. Type: GUYANA. Ayanganna Plateau, Chinowieng village, 21-VII-1960, S.S. Tillett, C.L. Tillett \& R. Boyan 44892 (Holotype NY, mixed with H. leprieuri; photocopy, drawing and fragment of the holotype RENZ).

\section{Figure 1L-M}

Specimens examined: VENEZUELA. Bolívar: Gran Sabana, Santa Elena de Uairén, 9-X-2005, J.A.N. Batista 1594 (BHCB).

Distribution: Brazil (DF, GO, MG), Guyana and Venezuela.
Illustration: Foldats (1969, Figure 20, as $H$. mesodactyla).

There is no known material of this species from northern Brazil, however it occurs in Venezuela, where it was collected a few meters from the Brazilian border and reaches the central region of the "cerrado" biome, where it is common in some localities. Thus, it is likely that the species occurs and will eventually be found in northern Brazil, at least in the state of Roraima. Distinctive features of this species are the linear-setaceous leaves, the small flowers (dorsal sepal ca. $3 \times 2.5 \mathrm{~mm}$ ), the ovary which spreads from the rachis and the bracts usually shorter than half the length of the pedicellate ovary, even in the lower flowers in the inflorescence. Flowers are mainly green and the species is typical of humid places. Flowering time in central Brazil as well as in Venezuela occurs at the end of the rainy season.

7. Habenaria candolleana Cogn. in Mart., Fl. Bras. 3(4): 73. 1893. Type: BRAZIL. GoyAz: near Natividade, II-1840, G. Gardner 3991 (Isotypes BM, K, NY, OXF, P).

Figure 2A-C

Specimens examined: BRAZIL. Mato Grosso: Luciara, 19-III-1997, V.C. Souza et al. 14539 (ESA); PARÁ: Serra do Cachimbo, 17-XII-1956, J.M. Pires et al. 6392 (IAN, NY, RENZ).

Distribution: Brazil (DF, GO, MT, PA, TO).

This species is typical of the northern part of the "cerrado" biome, but occasionally enters the savannahs on rocky soil of the Amazon region. In flower morphology it is similar to $H$. goyazensis, but $H$. candolleana is distinguished by the leaves that are concentrated on the stem base (vs. spread along the stem), the lax inflorescence with 2-4 flowers (vs. 6-30 in H. goyazensis), the green sepals and white petals and lip (vs. green petals and lip), and the spur which is as long or a little longer than the pedicellate ovary (vs. about twice the length of the pedicellate ovary in $H$. goyazensis). The species occurs in seasonally humid places.

8. Habenaria dentifera Schweinf., Bot. Mus. Leaf. Harvard Univ. 9(3):46, figures 5-6. 1941. Type: PERU. JunIn, VI-1929, E.P. Killip \& A.C. Smith 23841 (Holotype F, n.v.; Isotypes AMES, NY, US; photocopy and drawing of the isotype RENZ).

Figure 2D-F

Specimens examined: BRAZIL. Amazonas: Taracuá, upper Rio Negro, 12-VI-1962, J.M. Pires \& N.T. Silva 8058 (IAN); Mato Grosso: Juina, 19-IV-1985, J.A.F. da Costa 702 (R). 
Distribution: Brazil (AM, MT), Ecuador and Peru. Illustration: Pabst \& Dungs (1975, Figure 90, as H. strictissima var. odontopetala).

This is an uncommon species in Brazil known just from the two collections mentioned above. The specimen in the collection Pires \& Silva 8058 was identified by Pabst (1962) as H. odontopetala Rchb. f. However, although the two species are similar, the flowers of $H$. dentifera have a prominent anterior petal (ca. $2 \mathrm{~mm}$ long) about half the length of the posterior petal (vs. reduced to a denticulate projection ca. $1 \mathrm{~mm}$ long and about $1 / 5$ the length of the posterior petal in $H$. odontopetala). The species occurs in forests or "caatinga" and the flowers are recorded as green.

9. Habenaria depressifolia Hoehne, Bot. Jahrb. Syst. 68: 136, Tafel 23. 1937. Type: BRAZIL. AmAPÁ: Macapá, 24-IV-1924, J.G. Kuhlmann 2072 (Holotype RB; Isotypes AMES, SP).

Figure 2G-H

Specimens examined: BRAZIL. AMAPÁ: Macapá, 16-IV-1982, N.A. Rosa et al. 4235 (CEN, HRB, INPA, MG, NY); PARÁ: Ourém, 1-V-1994, J.B.F. da Silva 303 (MG), Maracanã, 6-IV-1980, G. Davidse et al. 17951 (NY).

Distribution: Brazil (AP, DF, GO, PA).

Among the Habenaria species from the Amazon region, $H$. depressifolia is very distinctive by the orbicular, fleshy, reticulate leaves that are adpressed to ground. Among other Brazilian species it is similar to H. schenckii Cogn., but the two species differ in the development of the leafs (the larger leafs are about 2-3 x 2-3.5 cm in $H$. depressifolia vs. $3.5-5 \times 4.5-7 \mathrm{~cm}$ in $H$. schenckii) and size of the flowers (dorsal sepal 3.5-5 x 3-4 mm and anterior petal 4-6 $\mathrm{mm}$ long in $H$. depressifolia vs. 6-7 x 3.5-4 $\mathrm{mm}$ and about 7-9 $\mathrm{mm}$ long, respectively, in $H$. schenckii). Flowers are completely green and the species grows in permanently dry, rocky places as well as in seasonally humid fields.

10. Habenaria glazioviana Kraenzl. ex Cogn. in Mart., Fl. Bras. 3(4):84. 1893. Type: BRAZIL. MinAs Gerais: Serra do Caraça, A.F.M. Glaziou 14295 (Holotype BR; Isotype $\mathrm{P}$ ).

Figure 2I-J

Specimens examined: BRAZIL. Amazonas: Manicoré, 15-IV-1985, C.A. Cid Ferreira 5575 (HRCB, NY, UB); PARÁ: Conceição do Araguaia, 24-II-1980, T. Plowman et al. 9095 (MG, NY, RENZ), São Geraldo do Araguaia, 23-IV-2004, G. Pereira-Silva et al. 9035 (CEN), Ourilândia do Norte, 26-II-1999, M.R. Cordeiro
2871 (IAN); RondÔNIA: road Porto Velho-Cuiabá, 9-II-1983, L.O.A. Teixeira et al. 1392 (INPA, MG).

Distribution: Brazil (AM, BA, GO, MG, MS, MT, PA, PB, PE, RO, SP, TO).

Illustration: Silva \& Silva (2004, p.253).

This species is very similar and undoubtedly close related to $H$. pratensis (Salzm. ex Lindl.) Rchb. f. The main difference is the width of the midlobe of lip and petal posterior segment, which are very broad and expanded in $H$. glazioviana and narrower in $H$. pratensis (midlobe of lip 9-22 mm wide vs. ca. 2-5 mm wide in $H$. pratensis). In the coast restingas of northeastern Brazil the two species can occur side by side and the existence of intermediate forms makes identification difficult. Further studies are still necessary to determine the exact relation between the two taxa. Flowers are pale yellow and the species is usually found in seasonally humid places.

11. Habenaria goyazensis Cogn. in Mart., Fl. Bras. 3(4):77. 1893. Type: BRAZIL. GoIÁs: near Conceição, II-1840, G. Gardner 3995 (Isotypes BM, K, OXF; photocopy, drawing and fragment of isotype RENZ).

Figure 2K-L

Specimens examined: BRAZIL. PARÁ: Marajó, 1877-1878, Jobert 141 (P, RENZ); TocANTINS: Araguaçu, 16-II-1997, J.A.N. Batista et al. 683 (CEN). GUYANA. VIII-1948, G. Wilson-Browne 2 (K, RENZ, image seen).

Distribution: Brazil (GO, MG, MT, PA, PE, SE, TO) and Guyana.

This is an uncommon species. In Northern Brazil it is known only by a 127 years old collection by Jobert from the island of Marajó. In the "cerrado" the species grows in seasonally humid places. Flowers are mainly green, with the base of the petals and lip white. The name H. goyazensis was mistakenly applied by Hoehne (1940) and Pabst (Pabst \& Dungs 1975) to the species now known as $H$. longipedicellata (northern Brazil) and $H$. tamanduensis Schltr. (centralwest and southeastern Brazil). However, $H$. goyazensis has a short pedicel (ca. 5-6 mm long) and a spur about twice the size of the pedicellate ovary, while $H$. longipedicellata and $H$. tamanduensis have markedly long pedicels (15-30 mm long) and the spur and pedicellate ovary are about the same length.

12. Habenaria hamata Barb. Rodr., Gen. Sp. Orchid. 1: 162. 1877. Type: BRAZIL. São Paulo: Retiro da Lagem, III-1857, A.F. Regnell III-1158 (Isotypes S, SP).

Figure 3A-D

Selected specimens examined: BRAZIL. AmAPÁ: Macapá, 21-V-1944, A.M. Bastos s.n. (HB2159, 

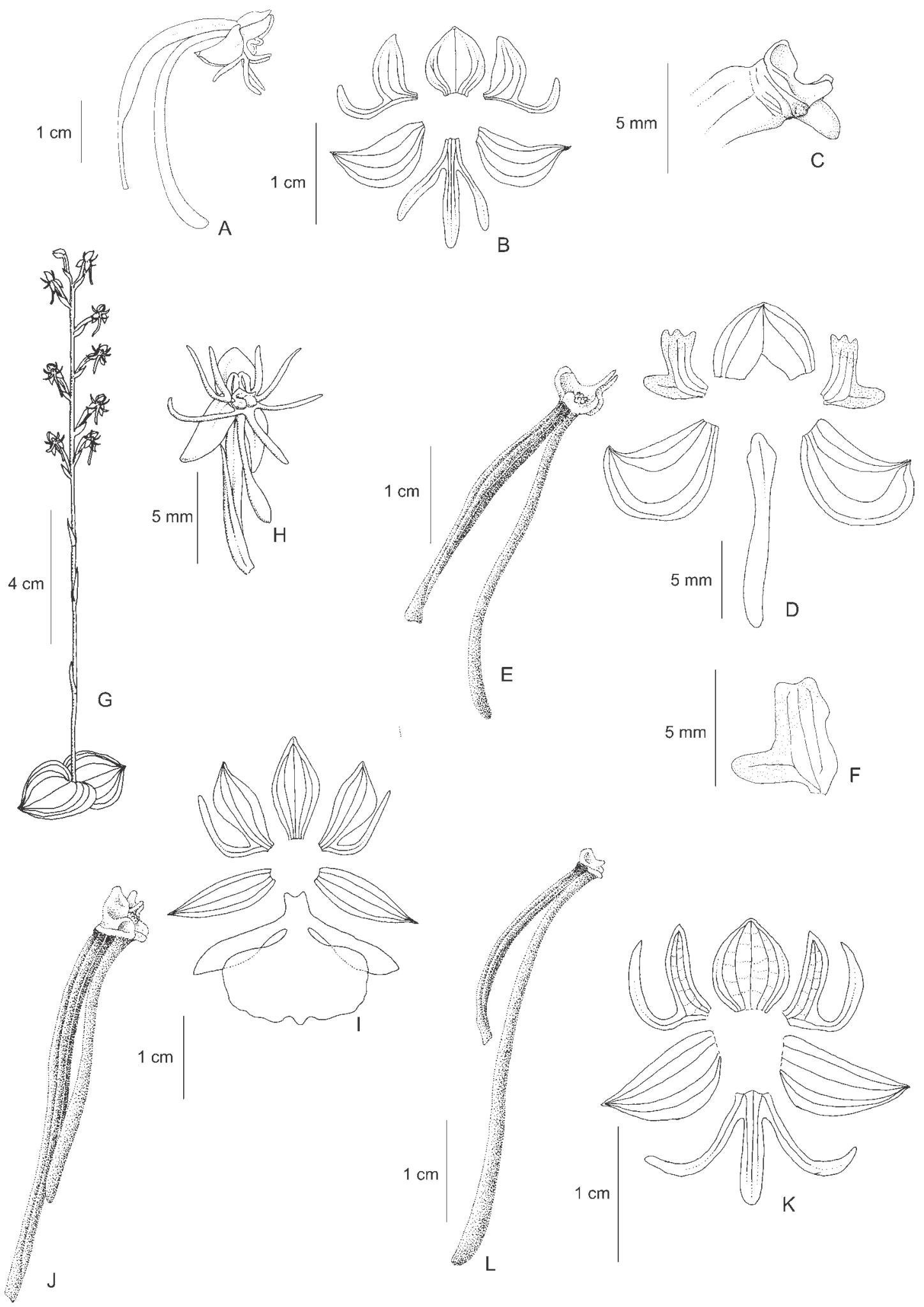

Figure 2. A-C. Habenaria candolleana Cogn. A. Flower. B. Perianth. C. Column, side view. D-F. Habenaria dentifera Schweinf. D. Perianth. E. Ovary, column and spur. F. Petal. G-H. Habenaria depressifolia Hoehne. G. Habit. H. Flower. I-J. Habenaria glazioviana Kraenzl. ex Cogn. I. Perianth. J. ovary, column and spur. K-L. Habenaria goyazensis Cogn. K. Perianth. L. Ovary, column and spur. (A-C. Pires et al. 6392 (IAN); D-E. J.A.F. da Costa 702 (R); F. Pires \& Silva 8058 (IAN); G-H. Rosa et al. 4235 (MG); I-J. Cordeiro 2871 (IAN); K-L. Batista et al. 683 (CEN)). All figures drawn from dried material. 
RB58418), Tartarugalzinho, 23-V-2001, L.A. Pereira et al. 467 (MG); PARÁ: Oriximiná, 30-V-2004, J.B.F. da Silva 1381 (IAN). FRENCH GUIANA. 9-VI-1989, G. Cremers \& M. Hoff 10717 (RENZ, image seen).

Distribution: Brazil (AP, BA, DF, GO, MG, PA, PB, PE, PI, SP, TO) and French Guiana.

This species is similar and undoubtedly closely related to $H$. obtusa and $H$. seticauda, but distinct by the not imbricate bracts (vs. imbricate and covering most of the rachis in $H$. obtusa and $H$. seticauda), usually larger flowers (midlobe of lip 25-36 mm long in $H$. hamata vs. 10-18 mm long in H. obtusa and H. seticauda), which spread from the stem, and the spur which is free from the bracts and hook shaped or sinuous (vs. usually completely enclosed between the bracts and straight in $H$. obtusa and H. seticauda). Sepals are green and white, the petals mainly white and the lip green. The species occurs in humid as well as in dry places.

13. Habenaria heptadactyla Rchb. f., Linnaea 22: 812. 1849. Syntypes: VENEZUELA. s.d., Humboldt \& Bonpland (not located, n.v.), Monagas, Caripe, s.d., Moritz 615 (Syntype BM; photocopy and drawing of the syntype RENZ). GUYANA. s.d., R. Schomburgk s.n. (Syntype W; Syntype photocopy RENZ).

Figure 3E-F

Selected specimens examined: BRAZIL. AmAZONAS: Rio Negro, Barra, X-1850-III-1851, R. Spruce s.n. (AMES, BM32707, RENZ, MG19354, P, W), Campo de Janauari, s.d., R. Spruce 1222 (K), Humaitá, 23-XII-1979, A. Janssen \& I. Gemtchujnicov 62 (INPA); Mato Grosso: crossroad of highways Cuiabá-Santarém and Porto Velho, 4-II-1979, M.G. Silva \& A. Pinheiro 4434 (INPA, MG); Roraima: Boa Vista, Rio Branco, VIII-1913, J.G. Kuhlmann 786 (AMES, RB, SP), Igarapé Caranã, 20-VIII-1951, G.A. Black 51-12774 (IAN).

Distribution: Bolivia, Brazil (AM, DF, GO, MS, MT, RR, TO), Colombia, Guyana, Panama, Surinam, Trinidad and Tobago, and Venezuela.

Illustrations: Pabst \& Dungs (1975, Figure 124), Dunsterville \& Garay (1979, Figure 339), Snuverink \& Westra (1983, Figure 8), Kenny (1998, p.17 as H. leprieuri, p.18 as H. leprieuri var. heptadactyla), Silva \& Silva (2004, p.250 as H. leprieuri), Carnevali et al. (2003, p.384, Figure 351).

This species is similar and apparently closely related to $H$. leprieuri and $H$. schwackei, but distinct by the congest inflorescence with many bright yellow flowers. Habenaria leprieuri has a lax inflorescence and completely green flowers, and $H$. schwackei has a longer pedicel (about 8-9 mm long vs. 2-3 $\mathrm{mm}$ long in $H$. heptadactyla), slightly larger flowers (dorsal sepal 4-5.5 x 3.5-4 mm in H. schwackei vs. 3-3.5 x 2-3 mm in H. heptadactyla) with white petals and lip. Habenaria heptadactyla grows mainly in seasonally humid places, but can also be found in rocky soil in drier areas.

14. Habenaria hexaptera Lindl., Gen. Sp. Orchid. Pl.: 316. 1835. Type: BRAZIL. Minas Gerais: s.d., C.F.P. Martius s.n. (Holotype M; drawings of type by Lindley K).

Figure 3G

Selected specimens examined: BRAZIL. PARÁ: Alto Tapajós, Rio Cururu, village Pratati, 11-II-1974, W.R. Anderson 10755 (HB, IAN).

Distribution: Bolivia, Brazil (BA, CE, DF, ES, GO, MA, MG, MT, PA, PE, RJ, SP, TO), Colombia, Peru, and Venezuela.

This species is very similar to $H$. alata Hook., known from northern South America and Central America, and a detailed investigation is still necessary to determine the exact relation between them. The only records of $H$. hexaptera in Northern Brazil are from the "cerrados" over white sand of the Alto Tapajós. Flowers are completely green and the species is typical of dry places.

15. Habenaria huberi Carnevali \& Morillo, Ernstia 19: 6. 1983. Type: VENEZUELA. AmAzonAs: Atures, Huber 4542 (Holotype VEN) n.v.

\section{Figure 3H-I}

Specimens examined: BRAZIL. RondônIA: Presidente Médici, 11-III-1986, N.A. Rosa et al. 4932 (MG).

Distribution: Brazil (RO) and Venezuela.

Illustration: Carnevali et al. (2003, p.384, Figure 350).

This is the first record of $H$. huberi for Brazil. Habenaria huberi is similar and close related to $H$. pratensis, but apparently distinct by the color of the flowers (orange vs. pale yellow in $H$. pratensis) and the lateral segments of the lip (distinctly spatulate vs. linear or discreetly spatulate in $H$. pratensis). Habenaria huberi differs from $H$. spathullifera by the color of the flowers (orange vs. bright yellow) and size of pedicellate ovary (3-3.7 cm long vs. 1.6-2.5 cm long in $H$. spathullifera), and from $H$. glazioviana by the color of the flowers (orange vs. pale yellow) and narrower segments of the posterior petal and lip (midlobe of lip about $5 \mathrm{~mm}$ wide vs. $9-22 \mathrm{~mm}$ wide in $H$. glazioviana).

16. Habenaria aff. josephensis Barb. Rodr., Gen. Sp. Orchid. 2: 257. 1882. Type: BRAZIL. Minas Gerais: Serra de S. José d'El Rey, s.d., Barbosa-Rodrigues s.n. 


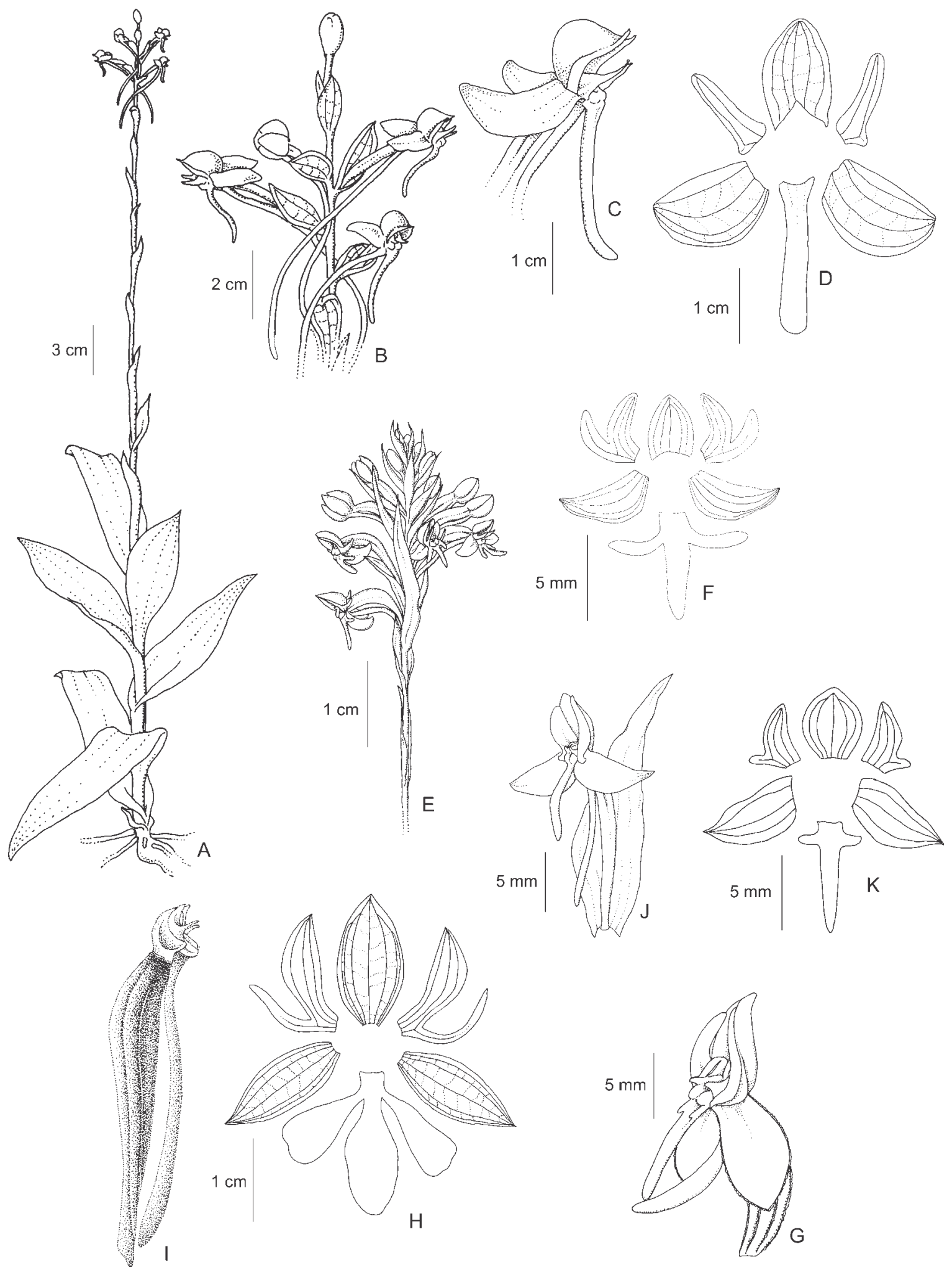

Figure 3. A-D. Habenaria hamata Barb. Rodr. A. Habit. B. Inflorescence. C. Flower. D. Perianth. E-F. Habenaria heptadactyla Rchb. f. E. Inflorescence. F. Perianth. G. Habenaria hexaptera Lindl., flower. H-I. Habenaria huberi Carnevali \& Morillo. H. Perianth. I. Ovary, column and spur. J-K. Habenaria aff. josephensis Barb. Rodr. J. Flower. K. Perianth. (A-D. J.B.F. Silva 1381 (IAN); E-F. Silva \& Pinheiro 4434 (MG); G. Anderson 10755 (IAN); H-I. Rosa et al. 4932 (MG); J. Pinheiro \& Carvalho 421 (IAN); K. Coelho et al. 1744 (INPA)). All figures drawn from dried material. 
(Holotype unknown, presumably lost. Original illustration by Barbosa-Rodrigues in Iconographie des Orchidées du Brésil, v.1, t.19 RB, copy K. Reproduced in Sprunger 1996. v.1: 72).

Figure $3 \mathrm{~J}-\mathrm{K}$

Specimens examined: BRAZIL. ACRE: Rio Branco, 13-V-1980, L. Coelho et al. 1744 (INPA); PARÁ: EstreitoMarabá, 8-IV-1974, G.S. Pinheiro \& J.F.V. Carvalho 421 (IAN).

The exact identity of this taxon is unclear. It is similar to H. josephensis, known from the "Mata Atlântica" in the southern, southeastern and northeastern regions of Brazil, but distinct by the larger leaves concentrated in the middle of the stem (vs. the larger leaves concentrated on the lower part of the stem in H. josephensis) and shorter anterior petal segment (1 mm long vs. 1.5-2.5 mm long in $H$. josephensis) with a truncate or obtuse apex (vs. acute in $H$. josephensis).

17. Habenaria lehmanniana Kraenzl., Bot. Jahrb. Syst. 16: 97. 1892. Type: COLOMBIA. Cauca: $1750 \mathrm{~m}$, 26-II-1884, F.C. Lehmann 3689 (Holotype G, n.v.; Holotype photocopy RENZ).

Figure 4A-D

Specimen examined: BRAZIL. RoRAIMA: Pacaraima village, 18-VI-1999, J.B.F. da Silva 827 (MG).

Distribution: Brazil (RR), Colombia and Venezuela. Illustrations: Silva \& Silva (2004, p.253 as H. repens, p.255 as H. amazonica).

This species is remarkably similar to $H$. longipedicellata. One of the most significant differences is the apex of rostellum midlobe, which is projected beyond the anthers in both species, but is broad and truncate in $H$. lehmanianna and narrow and acute in $H$. longipedicellata. The development of the vegetative parts and number of flowers is variable in both species. Habenaria lehmanianna is concentrated in high altitude areas of Colombia and Venezuela, but sporadically enters northern Brazil in the state of Roraima. The collection J.B.F. da Silva 827 is the first confirmed report of $H$. lehmanianna for Brazil. The record of $H$. lehmanianna for French Guiana is doubtful as the report by Renz (1992) is based on the collection Veyret 1619 which is, in our opinion, referable to $H$. longipedicellata. Sepals are green and the petals and lip light green with a whitened base.

18. Habenaria leprieuri Rchb. f., Linnaea 19: 376. 1846. Type: FRENCH GUIANA. Cayenne, 1839, Leprieur 132 (Holotype W; Isotype P).
= Habenaria culmiformis Schltr., Bot. Centralbl. Beih. 42(2):70. 1925. Type: BRAZIL. RorAImA: Rio Branco, VIII-1913, J.G. Kuhlmann 779 (Holotype B, destroyed; Isotypes AMES, RB, SP).

Figure 4E-G

Selected specimens examined: BRAZIL. AmAPÁ: Amapá, 19-IV-1950, G.A. Black \& I. Lobato 50-9511 (IAN); PARÁ: Marapanim, 16-VI-1991, M.N. Bastos et al. 1062 (MG), Maracanã, 13-VI-1994, M.N. Bastos et al. 1680 (MG), Conceição do Araguaia, 10-II-1980, T. Plowman et al. 8661 (MG, NY, RENZ), Vigia, 16-V-1952, R.L. Fróes 27840 (IAN, SPF, SP); Roraima: Boa Vista, 17-VII-2002, L.B. Bianchetti 1719b (CEN). VENEZUELA. Bolívar: Gran Sabana, Santa Elena de Uairén, 9-X-2005, J.A.N. Batista 1595 (BHCB).

Distribution: Brazil (AP, DF, GO, MG, MT, PA, RR, SP, TO), French Guiana, Guyana, Surinam, Trinidad \& Tobago and Venezuela.

Illustrations: Mansfeld (1930, Tafel 2, Figure 5, type illustration of $H$. culmiformis), Pabst \& Dungs (1975, Figure 117), Renz (1992, Plate 1a), Kenny (1998, p.18, as $H$. mesodactyla).

Renz (1992) considered H. culmiformis a synonym of $H$. leprieuri and we follow this position here. Distinctive features from other closely related species such as $H$. alpestris and $H$. heptadactyla are the completely green flowers and the width of the lateral sepals (1 $\mathrm{mm}$ in $H$. leprieuri and 1.5-2 $\mathrm{mm}$ in H. alpestris and H. heptadactyla). Also, the flowers are spaced in the inflorescence and the ovary is mostly parallel to the inflorescence axis and at least half covered by the bracts. The species is typical of humid places, usually growing in areas with water over the soil.

19. Habenaria longicauda Hook., Bot. Mag. 4, t.2957. 1829. Type: GUYANA. Demerara, s.d., C.S. Parker s.n. (Holotype K; Isotype K).

Figure $4 \mathrm{H}-\mathrm{K}$

Selected specimens examined: BRAZIL. PARÁ: Bragança, 15-VI-1989, J.B.F. da Silva 03 (MG), Melgaço, Estação Cientifica Ferreira Pena, 13-X-1995, J.B.F. da Silva 476 (MG), Belém, 1-V-1947, J. Murça Pires \& G. Black 1538 (IAC, IAN, P, RB), Almeirim, 16-IV-1923, A. Ducke s.n. (RB18720, SP31494).

Distribution: Brazil (BA, MA, PA), French Guiana, Guyana, Surinam, and Venezuela.

Illustrations: Foldats (1969, Figure 29, as H. sartor), Snuverink \& Westra (1983, Figure 9), Werkhoven (1986, p.141), Silva \& Silva (2004, p.253), Chiron \& Bellone (2005, p.66, as H. seticauda). 


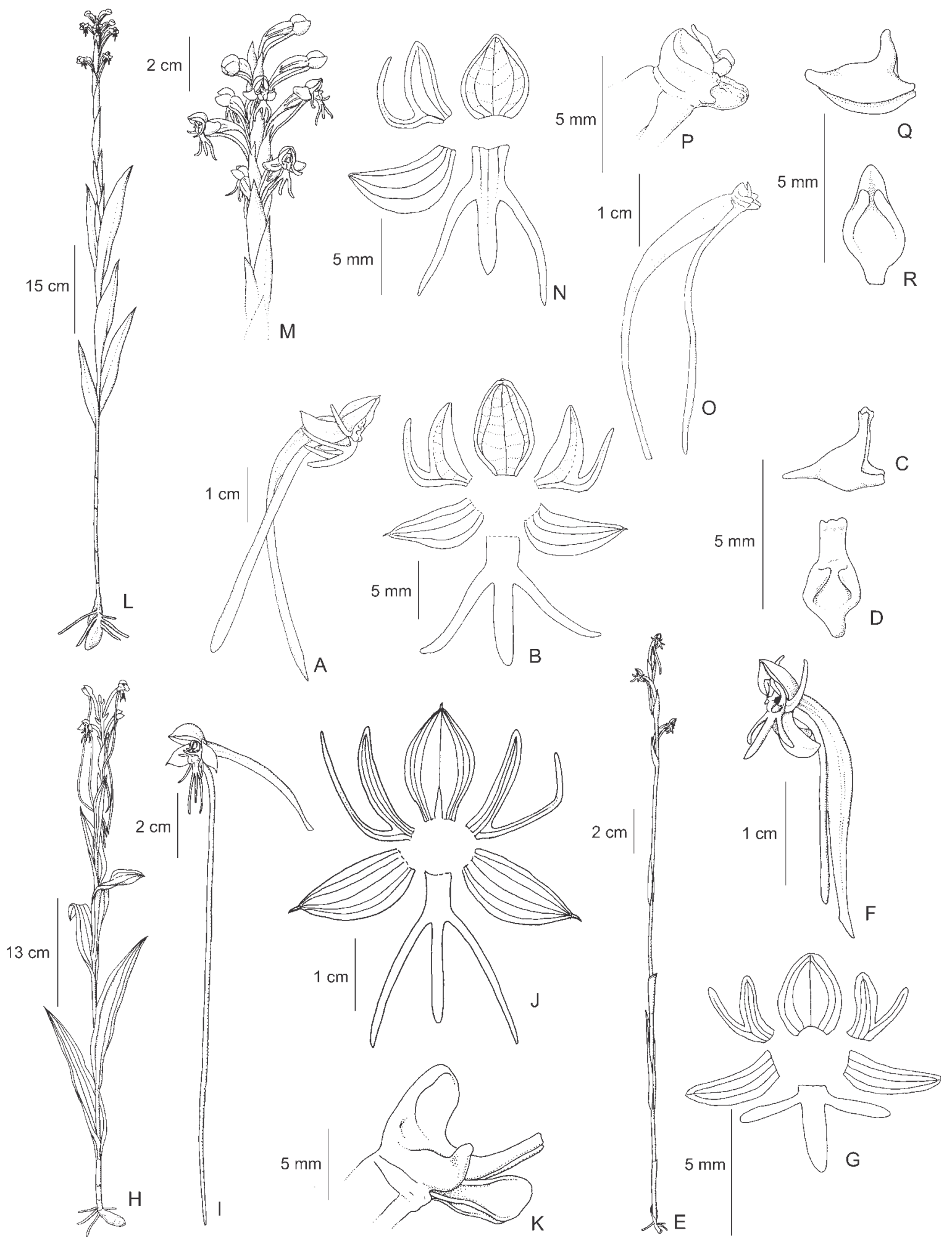

Figure 4. A-D. Habenaria lehmanniana Kraenzl. A. Flower. B. Perianth. C-D. Rostellum. C. Side view. D. Ventral view. E-G. Habenaria leprieuri Rchb. f. E. Habit. F. Flower. G. Perianth. H-K. Habenaria longicauda Hook. H. Habit. I. Flower. J. Perianth. K. Column. L-R. Habenaria longipedicellata Hoehne. L. Habit. M. Inflorescence. N. Perianth. O. Ovary, column and spur. P. Column, side view. Q-R. Rostellum. Q. Side view. R. Ventral view. (A-D. J.B.F. da Silva 827 (MG); E-G. Batista 1595 (BHCB); H-K. J.B.F. da Silva 03 (MG); L-R. J.B.F. da Silva 1050 (MG)). Figures A, B, C, D, E and G and drawn from dried material, figures F, H, I, J, K, L, M, N, O, P, Q and R from alcohol-fixed material. 
Habenaria longicauda is characterized by the long spur $(13-20 \mathrm{~cm})$ and long stigmas $(6-7 \mathrm{~mm})$ with involute margins. It is similar to $H$. nabucoi, but distinct by the lateral sepals reflexed (vs. not reflexed in $H$. nabucoi), flowers light green (vs. pure white in $H$. nabucoi), the midlobe of rostellum completely enclosed between the anthers (vs. partially exposed) and the spur acuminate, with an acute apex (vs. thickened and rounded). The species is typically aquatic, and occurs in water at the margins of lakes, streams and rivers. For more information about the species taxonomy and distribution see Batista et al. (2006).

20. Habenaria longipedicellata Hoehne, Bot. Jahrb. Syst. 68: 133, Tafel 19. 1937. Type: BRAZIL. PARÁ: Belém do Pará, 21-II-1927, A. Ducke s.n. (Holotype RB 19440; holotype fragments SP31823).

Figure 4L-R

Selected specimens examined: BRAZIL. AmAPÁ: Macapá, 1-V-1997, M.R. Cordeiro 2592 (IAN), Serra do Navio, III-1962, J.R. Mattos 11366 (SP); AmAZONAS: Manaus, 2-VII-1992, M. Nee 42904 (INPA, MBM, NY), Rio Negro, Unini River, 1-II-1975, M. Mee s.n. (HB63144); PArÁ: Castanhal, 7-V-1994, J.B.F. da Silva 309 (MG), Vigia, 8-V-1994, J.B.F. da Silva 315 (MG), Bragança, IV-2001, J.B.F. da Silva 1050 (MG), Marajó, Salvaterra, 23-IV-1980, N.A. Rosa 3625 (INPA, MG). FRENCH GUIANA. Cayenne, 10-V-1990, G. Cremers \& M. Hoff 11374 (RENZ, image seen), St. Elie, 16-V-1979, Y. Veyret 1619 (RENZ, U, image seen).

Distribution: Brazil (AM, AP, PA) and French Guiana.

Illustrations: Pabst \& Dungs (1975, Figure 97, as $H$. goyazensis), Silva \& Silva (2004, p.252 as H. petalodes), Chiron \& Bellone (2005, p.66, as H. rodeiensis).

Habenaria longipedicellata is very similar to $H$. lehmanniana, $H$. rodeiensis Barb. Rodr. and $H$. tamanduensis Schltr., and the exact identity of each of these taxa and the separation between them is not clear. Until a more detailed comparative study is done, we provisionally treat here all the material in this group from lowlands in the Brazilian Amazon as $H$. longipedicellata. Material of $H$. longipedicellata appears identified in the literature and in several herbaria as $H$. caldensis, $H$. lehmanniana and $H$. rodeiensis. Habenaria longipedicellata occurs in open areas as well as the borders or even inside forests. Along with $H$. trifida and $H$. petalodes, it is one of the few Habenaria species that can colonize disturbed habitats and sometimes is frequently found in pastures, road sides and other man made habitats. The flower segments have a white base which becomes green towards the apex.
21. Habenaria ludibundiciliata J. A. N. Bat. \& Bianch., Sitientibus 6(1):9. 2006. Type: BRAZIL. MARANHÃo: Carolina, 22-I-2003, J.A.N. Batista \& O.B. Oliveira Neto 1372 (Holotype CEN; Isotypes AMES, BHCB, HB, HUEFS, K, MBM, MO, NY, RB, SP, SPF, UEC).

Figure 5A-C

Selected specimens examined: BRAZIL. PARÁ: Serra do Cachimbo, 12-XII-1956, J.M. Pires et al. 6116 (IAN, NY, RENZ), Muaná, 21-IV-1982, M. Dantas \& Nivaldo 1008 (IAN), Santarém, 22-IV-2003, T. Sanaiotti s.n. (CEN), Marapanim, IV-1980, G. Davidse et al. 17867 (HRB); Roraima: Boa Vista, 19-VI-1999, J.B.F. da Silva 846 (MG). COLOMBIA. VAupes: cerro Yapoboda, 15-VIII-1960, Garay 103 (AMES).

Distribution: Brazil (DF, GO, MA, MT, PA, RR) and Colombia.

Illustration: Pabst \& Dungs (1975, Figure 116, as H. culicina),

This species is similar to $H$. mystacina Lindl. due to the small flowers and hairy segments of the flowers. However $H$. ludibundiciliata is typically from dry, rocky places (vs. seasonally humid for $H$. mystacina), has the inflorescence usually secund and lax (vs. compact and densely flowered in $H$. mystacina), has conspicuous aristate lateral sepals (vs. not aristate), the hairs are concentrated on the margins of the lateral segments of the petals and lip and occasionally are completely absent (vs. invariantly densely haired and covering the surface of the segments, including the lip midlobe), and occurs in the centralwest and northern regions (vs. restricted to the Espinhaço range in Minas Gerais and Bahia) (Batista \& Bianchetti 2006).

22. Habenaria macilenta (Lindl.) Rchb. f., Flora (Regensburg) 48: 180. $1865 \equiv$ Bonatea macilenta Lindl. in Benth., Hook. Lond. Journ. Bot. 2: 673. 1843. Type: GUYANA. s.d., R. Schomburgk s.n. (Holotype K; Isotype $\mathrm{W}$; drawings of isotype RENZ).

= Habenaria staminodiata Schltr., Bot. Centralbl. Beih. 42(2):74. 1925. (non Habenaria staminodiata Schltr., Repert. Spec. Nov. Regni Veg. 10: 3. 1911) 三 Habenaria staminodiifera Mansf., Repert. Spec. Nov. Regni Veg. 28: 93. 1930. Type: BRAZIL. RoRAIMA: Rio Branco, I-1913, J.G. Kuhlmann 781 (Holotype B, destroyed; Isotype RB)

\section{Figure 5D-F}

Specimens examined: BRAZIL. Distrito FedERAL: Brasília, 4-I-1995, J.A.N. Batista et al. 446 (CEN); MATO Grosso: Campos Novos da Serra do Norte, XI-1911, F.C. Hoehne 5566 (R); PARÁ: Ilha de Marajó, III-1950, 
R. Lima 77 (IAN), Muaná, 6-III-1970, E. Oliveira 5158 (IAN, SP); RoRAIMA: Boa Vista, 19-VII-1999, J.B.F. da Silva 850 (MG), Ilha de Maracá, 14-V-1987, W. Milliken 211 (INPA).

Distribution: Brazil (DF, GO, MG, MT, PA, RR, TO), French Guiana, Guyana, Surinam and Venezuela.

Illustrations: Mansfeld (1930, Tafel 6, Figure 24, type illustration of $H$. staminodiata), Pabst \& Dungs (1975, Figure 26), Snuverink \& Westra (1983, Figure 15), Batista \& Bianchetti (2002, Figures 2B, D).

In the general morphology of the flowers this species is similar to $H$. trifida, but distinct by the vegetative parts. In $H$. macilenta the plants are usually more slender and shorter (13-43 cm tall vs. (24-)40-76(-94) cm tall in $H$. trifida), the leaves $4-10 \times 0.4-1.1 \mathrm{~cm}$ (vs. $9-20 \times 0.9-2 \mathrm{~cm}$ in $H$. trifida), the larger leaves are usually on the lower part of the stem (vs. the larger leaves concentrated on the middle of the stem in H. trifida) and the internodes usually larger than the leaves (vs. smaller with the internodes usually covered by the leaves in H. trifida). Other differences are the the shorter pedicel $(1.5-3 \mathrm{~cm}$ long vs. 3-9.5 cm in H. trifida), the color of the petals and lip (yellowish vs. white in $H$. trifida) and column structure (Batista \& Bianchetti 2002). Sepals are green and the petals and lip yellowish. The species grows in marshes or seasonally humid places.

23. Habenaria nabucoi Ruschi, Bol. Mus. Biol. Prof. Mello-Leitão, Ser. Bot. 78: 1. 1973. Type: BRAZIL. Espirito Santo: Serra, I-1973, E. Colnago (Holotype MBML; Isotype HB).

Figure 5G-H

Selected specimens examined: BRAZIL. AmAZONAS: Labrea, 29-X-1968, G.T. Prance et al. 8057 (HB, INPA); Mato Grosso: cabeceira do rio Arinos, XI-1914, J.G. Kuhlmann 124 (R), J.G. Kuhlmann 125 (R).

Distribution: Brazil (AM, BA, DF, ES, MG, MT, PI, SP) and Venezuela.

Illustrations: Foldats (1969, Figure 30), Pabst \& Dungs (1975, Figure 12).

Habenaria nabucoi is similar and closely related to $H$. longicauda, but in $H$. nabucoi the flowers are usually larger and predominantly pure white (vs. light green in H. longicauda), the lateral sepals are not reflexed (vs. reflexed), the spur is thickened and rounded at the apex (vs. acuminate and acute) and the rostellum midlobe is taller and partially projected beyond the anthers (vs. smaller and enclosed between the anthers) (Batista et al. 2006). The species is typically aquatic and grows in water at the margins of lakes and streams.
24. Habenaria aff. nuda Lindl., Gen. Sp. Orchid. Pl. 312. 1835. Type: BRAZIL. Minas Gerais: s.d., C.F.P. Martius s.n. (Holotype M; drawings of type by Lindley K).

Figure 5I

Selected specimens examined: BRAZIL. PARÁ: Marabá, Serra de Carajás, 18-IV-1970, N. Cavalcante \& M. Silva 2630 (HB, MG, NY, RENZ), 14-III-1984, A.S.L. Silva et al. 1768 (INPA, MG, NY, RENZ).

In the area covered by the study, this taxon is found so far only in the rocky fields of the Serra dos Carajás in the state of Pará. It is similar to $H$. nuda, but a more precise identification is not possible at the moment since the exact identity of $H$. nuda is not clear. The material from northern Brazil is possibly identical to the material from French Guiana (de Granville et al. 6194, Sarthou 537) identified as H. rodriguezii Cogn. by Renz (1992). The relation between $H$. nuda and $H$. rodriguezii is unclear as the exact identity of $H$. rodriguezii is also not clear. Habenaria aff. nuda is also similar and can be confused with $H$. sprucei, but is distinct by the leaves, which are wider (4-8 mm wide vs. 3-4 mm wide in $H$. sprucei), not setaceous and the usually larger flowers (dorsal sepal 7-9 x 6.5-8 mm vs. ca. 6 x $5.5 \mathrm{~mm}$ in H. sprucei).

25. Habenaria obtusa Lindl., Gen. Sp. Orchid. Pl.: 315. 1835. Type: BRAZIL. Minas Gerais: Montis Itacolumi, s.d., C.F.P. Martius s.n. (Holotype M; drawings of type by Lindley $\mathrm{K}$ ).

= Habenaria ornithoides Barb. Rodr., Gen. Sp. Orchid. 1: 162. 1877. Type: BRAZIL. MinAs GERAIS: Uberaba, II-1849, A.F. Regnell ser. III-1185 (Isotypes BR fragment, P, S, SP).

Figure 5J-L

Selected specimens examined: BRAZIL. Distrito Federal: Brasília, 26-XII-1992, J.A.N. Batista 366 (CEN); PArá: Vigia, 12-VI-1966, G.F.J. Pabst 8964 (AMES, HB), Alto Tapajós, Rio Cururu, 13-II-1974, W.R. Anderson 10940 (HB, RENZ, IAN, NY).

Distribution: Brazil (BA, DF, GO, MA, MG, MS, MT, PA, PB, PE, PR, SE, SP, TO), Colombia, Ecuador, Guyana, Paraguay, Peru, Surinam, and Venezuela.

Illustrations: Foldats (1969, Figure 23), Dunsterville \& Garay (1979, Figure 342), Pabst \& Dungs (1975, Figure 89), Snuverink \& Westra (1983, Figure 11).

Habenaria obtusa and $H$. seticauda are very similar and differ basically in the development of the spur (2.6$5.5 \mathrm{~cm}$ vs. $8-9.5 \mathrm{~cm}$ in $H$. seticauda). Both taxa are similar to $H$. hamata, but distinct by the arrangement of the flowers (parallel and close to the inflorescence axis vs. spreading in $H$. hamata) and the imbricate bracts that 


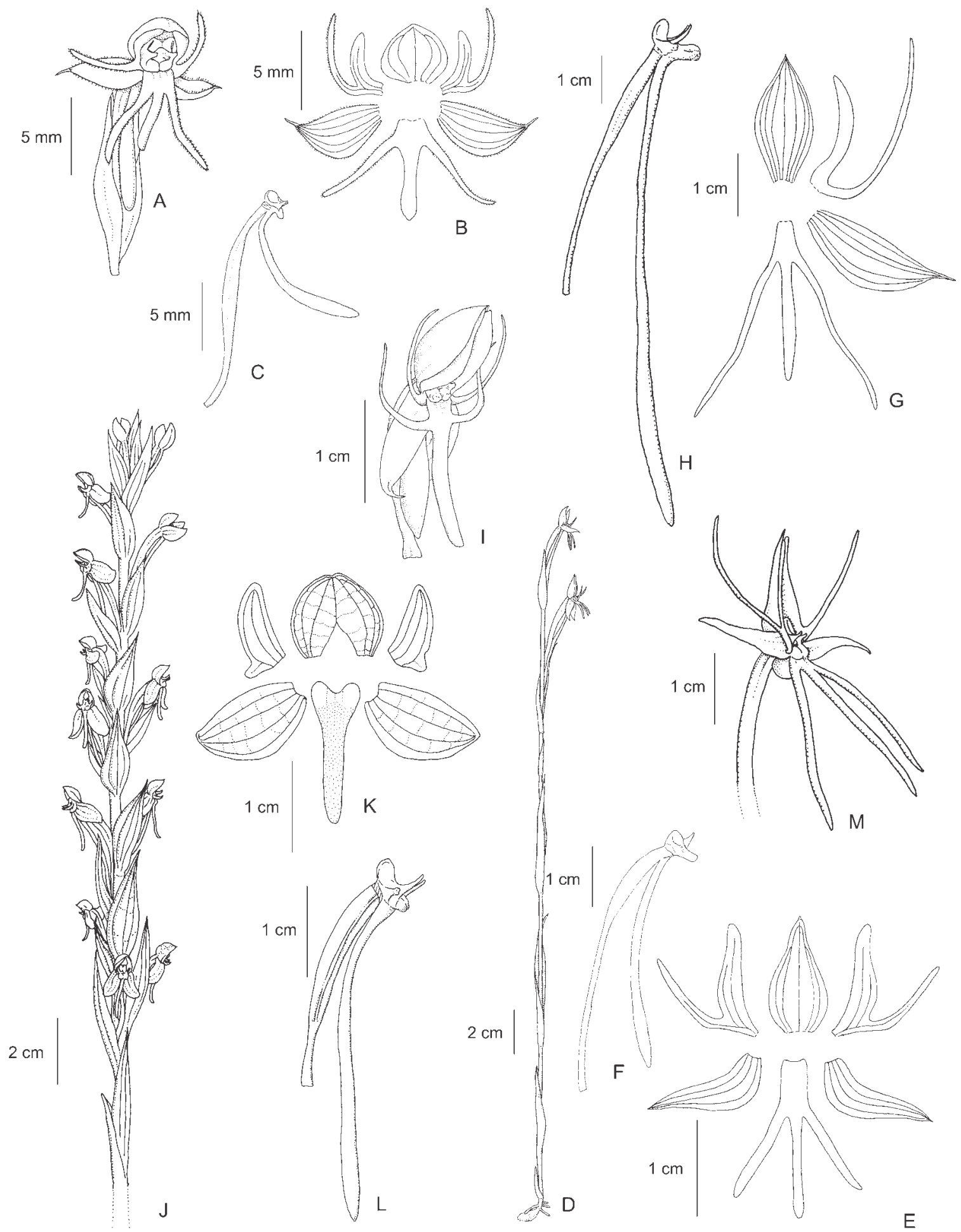

Figure 5. A-C. Habenaria ludibundiciliata J. A. N. Bat. \& Bianchetti. A. Flower. B. Perianth. C. Ovary, column and spur. D-F. Habenaria macilenta (Lindl.) Rchb. f. D. Habit. E. Perianth. F. Ovary, column and spur. G-H. Habenaria nabucoi Ruschi. G. Perianth. H. Ovary, column and spur. I. Habenaria aff. nuda Lindl., flower. J-L. Habenaria obtusa Lindl. J. Inflorescence. K. Perianth. L. Ovary, column and spur. M. Habenaria orchiocalcar Hoehne, perianth. (A-C. Batista \& Oliveira-Neto 1372 (CEN); D. Oliveira 5158 (IAN); E-F. Batista et al. 446 (CEN); G-H. Prance et al. 8057 (INPA); I. Silva et al. 1768 (MG); J. Fróes 27836 (IAN); K-L. Batista 366 (CEN); M. J.B.F. da Silva 219 (MG)). Figure A drawn from alcohol-fixed material, all other figures from dried material. 
usually cover the rachis and the spur (vs. the exposed rachis and free spur of $H$. hamata).

26. Habenaria orchiocalcar Hoehne, Comm. Linhas Teleg. Estrateg. Matto Grosso Annexo 5, Bot. 5: 42, tab. 85, figure 1. 1915. Type: BRAZIL. MAто Grosso: Campos Novos da Serra do Norte, XI-1911, F.C. Hoehne s.n. (Holotype lost; Lectotype designated by Batista and Bianchetti 2002: t.85, figure 1, loc. cit.).

$=$ Habenaria lancipetala Pabst, Orquidea 29(2):62, tab. 1.1967. Type: BRAZIL. Distrito Federal: Chapada da Contagem, 14-I-1966, H.S. Irwin et al. 11682 (Holotype $\mathrm{HB}$; Isotype UB).

Figure $5 \mathrm{M}$

Specimens examined: BRAZIL. MARANHÃo: Carolina, Pedra Caída, 10-I-2007, J.B.F. da Silva 1503 (BHCB); Mato Grosso: Luciara, 19-III-1997, V.C. Souza et al. 14490 (ESA); PARÁ: São Felix do Xingu, 18-XII-1993, J.B.F. da Silva 219 (MG).

Distribution: Brazil (DF, GO, MA, MS, MT, PA, TO).

Illustrations: Batista \& Bianchetti (2002, figs.1, 2A, C).

The distribution of this species ranges from the central to the northern part of the "cerrado" biome, where it borders and occasionally enters the Amazon region. In the vegetative parts the species is similar to H. macilenta, but $H$. orchiocalcar is distinct from all the other species in the region by the small (3-3.5 x 2.5-3 mm), ovoid, scrotiform, ventrally compressed spur. Sepals are green and petals and lip completely white and the species is typical of humid places (Batista \& Bianchetti 2002).

27. Habenaria parviflora Lindl., Gen. Sp. Orchid. Pl.: 314. 1835. Type: BRAZIL. BAHIA: s.d., Salzmann s.n. (Syntypes K, MPU, P; photocopy, drawing and fragment of the syntype RENZ); RIO DE JANEIRO: monte Corcovado, s.d., C.F.P. Martius s.n. (Syntype presumably at $\mathrm{M}, n . v$.).

Figure 6A-B

Specimens examined: BRAZIL. RoRAIMA: summit of Serra do Surucucu, XI-1992, J.B.F. da Silva \& A. Cardoso 640 (MG), Serra Surucucu, 23-I-1975, B.G.S. Ribeiro 15167-594 (IAN).

Distribution: Argentina, Brazil (BA, DF, ES, GO, MG, PR, RJ, RR, RS, SC, SP), Colombia, Ecuador, Guyana, Paraguay, Uruguay and Venezuela.

This species is particularly frequent in southeastern Brazil, but it reaches the Guiana shield and extends until Colombia and Ecuador. The species is uncommon in the Brazilian Amazon region and known so far only from the two collections above. Typical material of the species is characterized by the dense, many flowered inflorescences and small flowers (dorsal sepal 3-4 x 2-3 mm). The plants from northern Brazil are shorter and have less congest inflorescences, but are identical in flower morphology to typical material from southeastern Brazil. The flowers are completely green and the species is typical of humid places.

28. Habenaria petalodes Lindl., Gen. Sp. Orchid. Pl.: p.316. 1835. Type: BRAZIL. Minas GeraIs: Serra do Itacolumi, 21-28-IV-1818, C.F.P. Martius s.n. (Holotype M; drawings of type by Lindley $\mathrm{K}$ ).

\section{Figure 6C-F}

Selected specimens examined: BRAZIL. MARANHÃO: São Luiz do Maranhão, 3-VI-1907, A. Ducke 520 (RB); PARÁ: Maracanã, 12-IV-1991, M.N. Bastos et al. 730 (MG), Marapanim, 15-VI-1991, M.N. Bastos et al. 1028 (MG), Bragança, 13-III-1995, S. Monteiro \& M. Fernandez 398 (MG), Vigia, 5-VI-1994, J.B.F. da Silva 328 (MG), Icoaraci-Belém road, 24-II-1965, Grup. Soc. Parae. Orqu. 51 (HB), Ilha de Marajó, Maracá, IX-1969, P. Lacerda \& T. Guedes 130 (IAN).

Distribution: Brazil (BA, CE, DF, ES, GO, MA, MG, MS, PA, PB, PE, RJ, SE, SP) and Paraguay.

Habenaria petalodes is similar to $H$. quadrata, $H$. dentifera, $H$. avicula, and $H$. alterosula and many other extra Brazilian species such as $H$. odontopetala Rchb. f., H. floribunda Lindl., $H$. eustachya Rchb. f., $H$. autumnalis Poepp. \& Endl., H. selerorum Schltr., and H. socialis Fawcett \& Rendle, all characterized by growing in forests, by the well developed leaves, by the petals and lip mostly simple and by the column structure, with long, slender anther canals. However, H. petalodes is distinct from all of these closely related species by the completely simple, oblong-spatulate petals. Habenaria warszewiczii Schltr. from Panama is remarkably similar, but apparently distinct by the flowers about half the size of $H$. petalodes, according to the original author of the species (Reichenbach 1866). The material described and illustrated from Venezuela (Dunsterville \& Garay 1979) and identified as $H$. petalodes is, in our opinion, referable to $H$. odontopetala. Flowers of $H$. petalodes are completely green and the species occupies a broad range of habitats, from open fields to the border of forests. The species can also occupy man made habitats and is frequently found at the margins of roads and other disturbed areas.

29. Habenaria quadrata Lindl., Gen. Sp. Orchid. Pl.: 316. 1835. Type: BRAZIL. Amazonas: Rio Negro, flumen Madeira, s.d., C.F.P. Martius s.n. (Holotype M; 

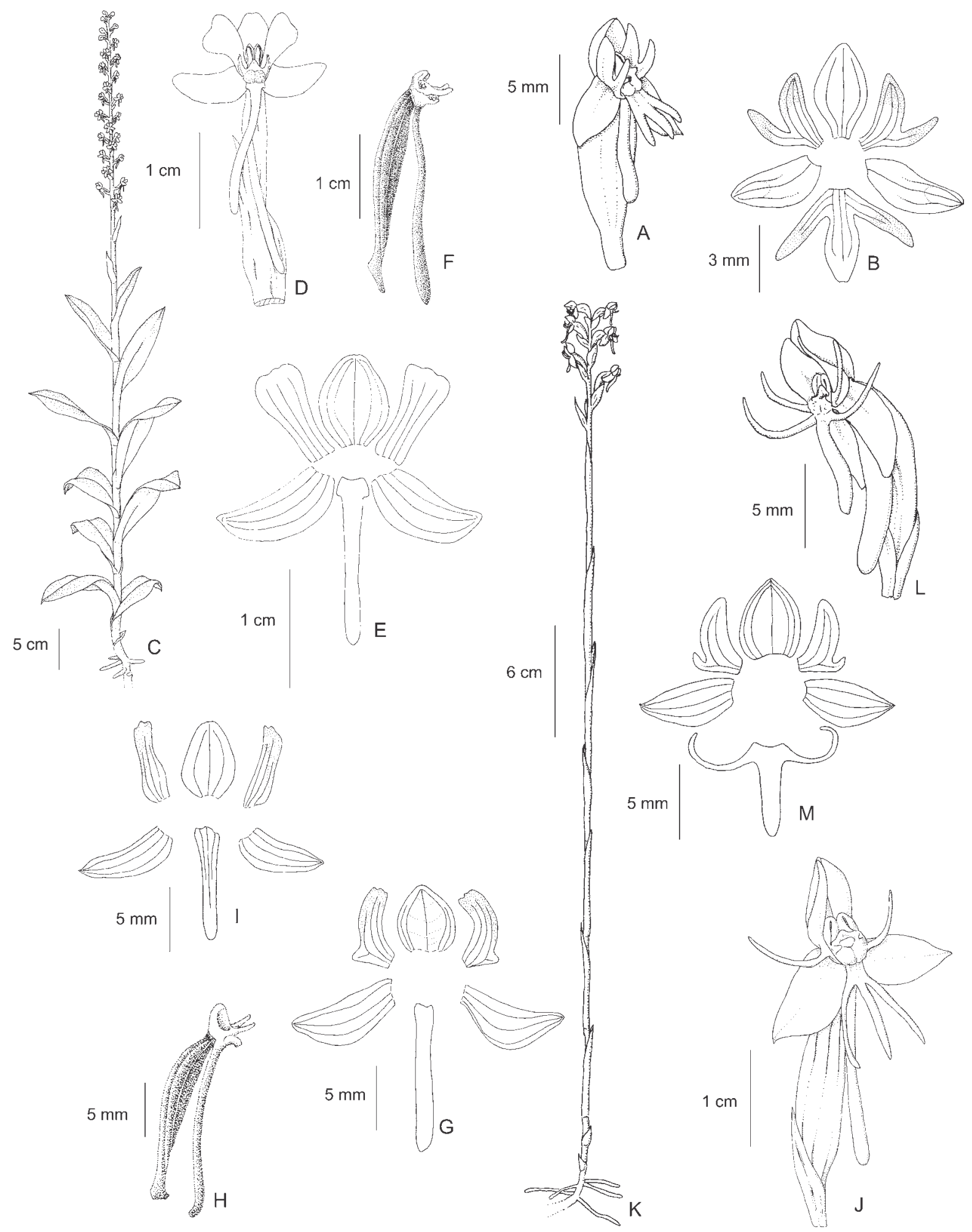

Figure 6. A-B. Habenaria parviflora Lindl. A. Flower. B. Perianth. C-F. Habenaria petalodes Lindl. C. Habit. D. Flower. E. Perianth. F. Ovary, column and spur. G-I. Habenaria quadrata Lindl. G. Perianth. H. Ovary, column and spur. I. Perianth. J. Habenaria repens Nuttall, flower. K-M. Habenaria roraimensis Rolfe. K. Habit. L. Flower. M. Perianth. (A-B. J.B.F. da Silva \& Cardoso 640 (MG); C-F. J.B.F. da Silva 328 (MG); G-H. Monteiro s.n. (INPA 81947); I. Maciel \& Welber 171 (INPA); J. J.B.F. da Silva 372 (MG); K-L. J.B.F. da Silva 463 (MG); M. Oliveira 239 (CEN)). Figures C-F drawn from alcohol-fixed material, other figures from dried material. 
photocopy and drawing of holotype RENZ; drawings of type by Lindley K).

Figure 6G-I

Specimens examined: BRAZIL. Amazonas: Manacapuru, 20-III-1979, O.P. Monteiro s.n. (INPA 81947); Mato Grosso: Barão de Melgaço, 4-I-1979, A. Maciel \& A. Welber 171 (INPA).

Distribution: Brazil (AM, MT).

The exact identity of $H$. quadrata has been controversial and Cogniaux (1893) included $H$. curvilabria as a synonym. The specimens in the two collections above are distinct from the typical $H$. curvilabria of central and southeastern Brazil by the size of the petals (6 x $1.5 \mathrm{~mm}$ vs. $2.5-3.5 \times 1.5-2.3 \mathrm{~mm}$ in H. curvilabria). They are similar to $H$. petalodes, but have smaller flowers (dorsal sepal 5-6 x 4-4.5 mm vs. ca. $8 \times 6 \mathrm{~mm}$ in $H$. petalodes), a shorter spur (15-17 mm long vs. ca. $25 \mathrm{~mm}$ long in $H$. petalodes) and petals that are not broad at the apex (vs. the spatulate petals of $H$. petalodes). Habenaria quadrata is similar to the extra Brazilian species $H$. odontopetala Rchb. f. and $H$. floribunda Lindl. and further studies are necessary to determine the exact relation between these species. Flowers are recorded as light green, and the species occurs in "varzea" forests and "terra firme capoeiras". Habenaria quadrata was recorded for Venezuela (Foldats 1969), but the report needs confirmation.

30. Habenaria repens Nuttall, Gen. N. Am. Pl. 2: 190, figure 10. 1818. Type: UNITED STATES OF AMERICA. Georgia \& Carolina: s.d., Nuttal s.n. (Holotype PH) n.v.

Figure 6J

Specimens examined: BRAZIL. PARÁ: Tucuruí, 24-III-1995, J.B.F. da Silva 372 (MG), Itupiranga, 7-II-1976, N.T. Silva 4287 (IAN), Santarém, 23-II-1981, M. Yamakashi 110 (INPA), lake of Curuá-Uma dam, VII-1980, P.S. Mera 326 (INPA). UNITED STATES OF AMERICA: SOUTH CAROLINA: Darlington, 6-VIII-1972, S.W. Leonard 5518 (SP).

Distribution: Throughout the neotropics, from southern USA to northern Argentina.

Illustrations: Foldats (1969, Figure 27), Dunsterville \& Garay (1979, Figure 344).

This species is typically aquatic, growing inside the water at the margins of lakes or other flooded places, over clamps of aquatic vegetation or even over floating, decaying dead tree trunks. Habenaria repens is similar to $H$. amambayensis, but distinct by the habitat, the smaller flowers (dorsal sepal ca. $4-5 \times 4.5 \mathrm{~mm}$ vs. ca. $7 \times 5 \mathrm{~mm}$ in H. amambayensis) and the shorter lateral segments of the petals and lip (4-7 $\mathrm{mm}$ in H. repens vs. ca. 12-15 mm in H. amambayensis). Flowers are completely green.

31. Habenaria roraimensis Rolfe, Trans. Linn. Soc. London, Ser. 2, Bot. 6(1):65. 1901. Type: GUYANA. Roraima, summit, 1808, F.V. Mc Connell \& J.J. Quelch 698 (Holotype K, n.v.; Isotype BM; photocopy of holotype RENZ).

\section{Figure 6K-M}

Specimens examined: BRAZIL. Amazonas: Santa Isabel do Rio Negro, Pico da Neblina, 14-IX-1995, J.B.F. da Silva 463 (MG). VENEZUELA. Bolívar: Gran Sabana, Mount Roraima, 23-VIII-1997, R.S. Oliveira 239 (CEN).

Distribution: Brazil (AM, RR), Guyana and Venezuela. Illustrations: Dunsterville (1972, Plate 10), Dunsterville \& Garay (1979, Figure 346).

This species is restricted to the high tepuis of the Guyana Highland (Renz 1992). The leaves may be completely apressed to the stem or have the apex spread. The lateral segments of the petals vary from inconspicuous to almost the size of the anterior petal segment. Flowers are green and the species grows in the shallow, but usually humid soil found over the rocky formations of the mountain summits.

32. Habenaria schwackei Barb. Rodr., Gen. Sp. Orchid. 2: 254. 1882. Type: BRAZIL. Paraná: Ponta Grossa, 13-I-1880, C.A.W. Schwacke 191 (Holotype R; Isotypes $\mathrm{R}, \mathrm{RB})$.

= Habenaria platydactyla Kraenzl., Kongl. Svenska Vetenskaps. Handl. 46(10):9, Tafel 2, Figure 5. 1911. Type: BRAZIL. Paraná: Capão Grande, 24-I-1910, $P$. Dusen 9089 (Holotype S; Isotypes HB, MBM, NY, P) syn. nov.

= Habenaria amazonica Schltr., Bot. Centralbl. Beih. 42(2):69. 1925. Type: BRAZIL. Roraima: Boa Vista, Rio Branco, I-1913, J.G. Kuhlmann 787 (Holotype B, destroyed; Isotypes AMES, RB, SP).

\section{Figure 7A-C}

Specimens examined: BRAZIL. GoIÁs: Alto Paraíso, 9-I-2001, J.A.N. Batista \& E.R. Pansarin 1147 (CEN); PARÁ: Ilha de Marajó, III-1950, R. Lima 76 (IAN); Tocantins: Palmas, 17-II-1997, J.A.N. Batista et al. 689 (CEN).

Distribution: Brazil (BA, GO, MA, MG, MT, PA, PR, RR, SP, TO), Colombia, French Guiana, Guyana, Paraguay, Surinam and Venezuela.

Illustrations: Mansfeld (1930, Tafel 1, Figure 2, type illustration of H. amazonica), Foldats (1969, Figure 19), Pabst \& Dungs (1975, Figure 111), Renz (1992, plate 2). 
Renz (1992) included H. amazonica under the synonymy of $H$. platydactyla. The examination of the type material of the two species and a large number of live and dried specimens from central Brazil and Paraná have confirmed the position held by Renz and shown that both species are identical to $H$. schwackei. The species is similar to $H$. heptadactyla and $H$. leprieuri, but distinct by the conspicuous pedicels (about 8-9 mm vs. 2-3 $\mathrm{mm}$ long in $H$. leprieuri and $H$. heptadactyla), the green sepals and white petals and lip (vs. the yellow petals and lip of $H$. heptadactyla and the green petals and lip of $H$. leprieuri), and the frequently broad lateral segments of the petals and lip (up to $2 \mathrm{~mm}$ broad vs. $0.5-0.75 \mathrm{~mm}$ broad in in $H$. leprieuri and $H$. heptadactyla). Habenaria schwackei is typical of seasonally humid places.

33. Habenaria secundiflora Barb. Rodr., Gen. Sp. Orchid. 2: 252. 1882. Type: BRAZIL. Minas Gerais: São João d' El-Rey, s.d., Barbosa-Rodrigues s.n. (Holotype unknown, presumably lost. Original illustration by Barbosa-Rodrigues in Iconographie des Orchidées du Brésil, v.1, t.10 RB, copy K. Reproduced in Sprunger 1996. v.1: 63).

\section{Figure 7D-E}

Specimens examined: BRAZIL. PARÁ: Jutahy de Almeirim, 19-IV-1923, A. Ducke s.n. (RB18721). VENEZUELA. BolívAR: Gran Sabana, Mount Roraima, 22-VIII-1997, R.S. Oliveira 234 (CEN).

Distribution: Brazil (DF, GO, MG, PA, PR, SP), Colombia, French Guiana, Guyana, and Venezuela.

Illustration: Dunsterville \& Garay (1979, Figure 340, as H. mesodactyla), Batista et al. (2004, Figures 1H, 3D).

This is a common species in Venezuela and in the "cerrado" of central Brazil but has been collected only once in the study area. A distinctive feature of the species is the petals which are entire for about $2 \mathrm{~mm}$ from the base and then divided above. The species was mistakenly identified as H. setacea Lindl. by Hoehne (1940, tab. 105, Figure 3), Pabst \& Dungs (1975, Figure 140) and Renz (1992), and as H. mesodactyla Griseb. by Dunsterville \& Garay (1979). Flowers are completely green and the species occurs in dry or seasonally humid places.

34. Habenaria seticauda Lindl., Hook. Lond. Journ. Bot. 2: 673. 1843. Type: GUYANA. Pirara, s.d., R. Schomburgk 219 (Holotype K; photocopy and drawing of isotype RENZ).

\section{Figure 7F-G}

Selected specimens examined: BRAZIL. RORAIMA: Pacaraima, 20-VI-1999, J.B.F. da Silva 851 (MG).
VENEZUELA. Bolívar: Gran Sabana, Santa Elena de Uairén, 9-X-2005, J.A.N. Batista 1596 (BHCB, CEN).

Distribution: Brazil (RR), Guyana and Venezuela. Illustration: Silva \& Silva (2004, p.251, as H. obtusa). In the length of the spur H. seticauda is similar to $H$. hamata, and we first suspected they were conspecific. Accordingly, material of $H$. hamata from French Guiana (Cremers \& Hoff 10717) was identified by Renz (1992) as $H$. seticauda. However, examination of material from Venezuela and Roraima in Brazil showed that $H$. seticauda is a distinct entity and in fact very similar to H. obtusa. The two taxa differ basically in the length of the spur, which is longer in $H$. seticauda $(8-9 \mathrm{~cm})$ than in H. obtusa $(3-5 \mathrm{~cm})$. Besides this, the only other difference is that $H$. seticauda is restricted to the Guianas shield while $H$. obtusa has a broad distribution. Considering the differences above, we prefer to keep the two entities as separate species, although the collection of material (G. Eiten \& L. Eiten 3869 - SP) with spurs of intermediate length $(6-7 \mathrm{~cm})$ at the state of Maranhão suggests that the separation of the two entities at the species level may not be justifiable. This is the first confirmed report of the species in Brazil, and other previous reports (Hoehne 1940, Pabst \& Dungs 1975, Silva et al. 1995, Silva \& Silva 2004) were based in misidentification. The lateral sepals are green, the dorsal sepal is white with a green base, petals are white and the lip is green with a white base. The spur has a white base and becames green towards the apex. The species occurs in open dry places or at the border of forests.

35. Habenaria spathulifera Cogn. in Mart., Fl. Bras. 3(4):86. 1893. Type: BRAZIL. Brasilia austro-orientali, s.d., A.F.M. Glaziou 10092 (Holotype BR; Isotype P). $=$ Habenaria pratensis (Salzm. ex Lindl.) Rchb. $\mathrm{f}$. var. parviflora Cogn. in Mart., Fl. Bras. 3(4):86. 1893. Syntypes: BRAZIL. Tocantins: between Natividade and Conceição, II-1840, G. Gardner 3994 (BM, K, NY, OXF, P, SP); Mato Grosso: Cuiabá, s.d., Riedel s.n. (BR) syn. nov.

= Habenaria mattogrossensis Kraenzl., Kongl. Svenska Vetenskaps. Handl. 46(10):14, Tafel 1, Figure 4. 1911. Type: BRAZIL. Mato Grosso: Espinheiros, 10-II1894, C.A.M. Lindman 2785 (Holotype S; Isotype S).

= Habenaria georgii Schltr., Bot. Centralbl. Beih. 42(2):86. 1925. Type: BRAZIL. Amazonas: auf Campos Cacáo-Pireira, s.d., G. Huebner 85 (Holotype $\mathrm{B}$, destroyed. No isotype located).

= Habenaria spathuliglossa Kraenzl. ex Hoehne, Flora Brasilica 12(1), tab. 113, figure 1. 1940. nomen nudum. 

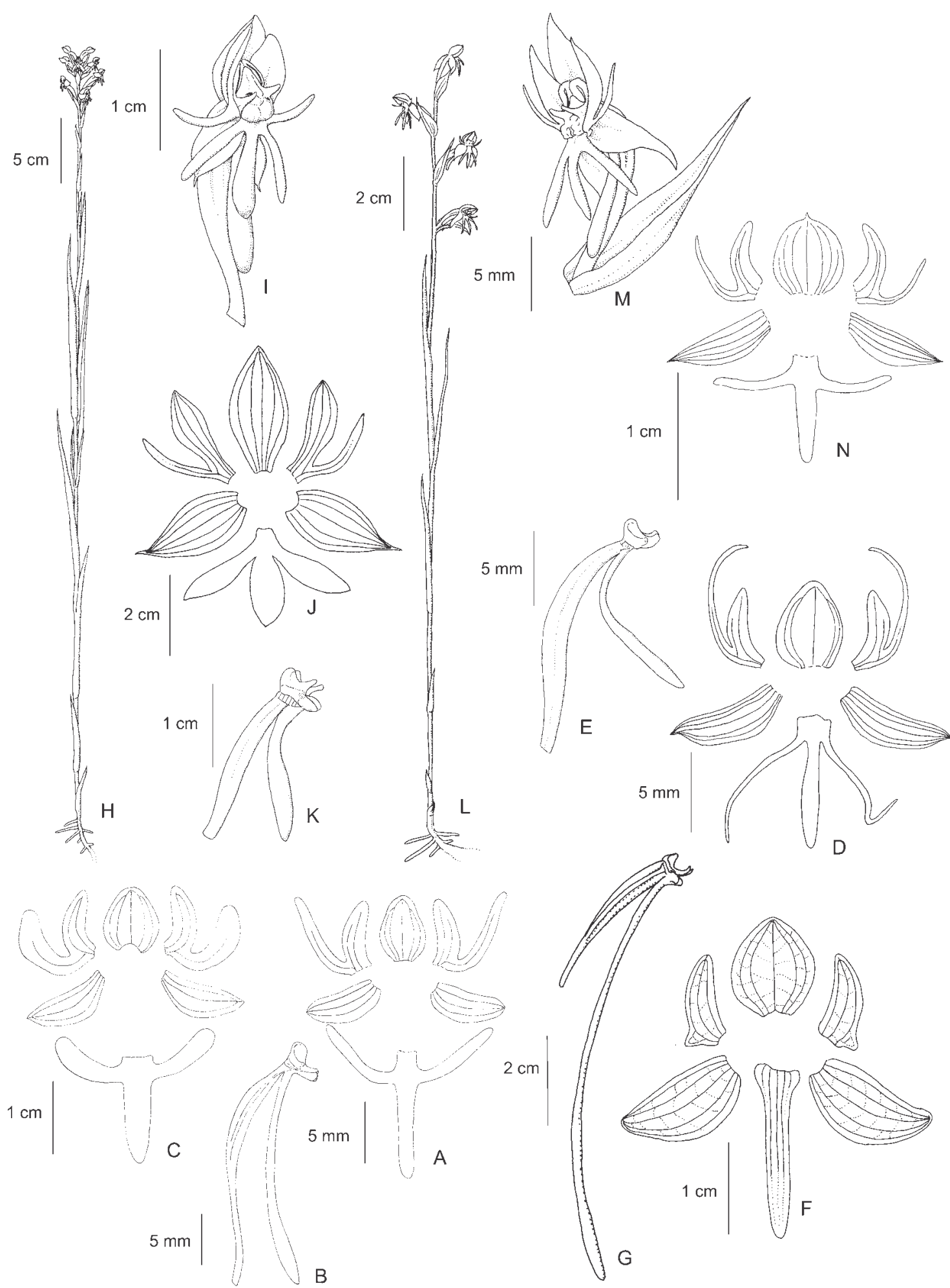

Figure 7. A-C. Habenaria schwackei Barb. Rodr. A. Perianth. B. Ovary, column and spur. C. Perianth. D-E. Habenaria secundiflora Barb. Rodr. D. Perianth. E. Ovary, column and spur. F-G. Habenaria seticauda Lindl. F. Perianth. G. Ovary, column and spur. H-K. Habenaria spathulifera Cogn. H. Habit. I. Flower. J. Perianth. K. Ovary, column and spur. L-N. Habenaria sprucei Cogn. L. Habit. M. Flower. N. Perianth. (A-B. Batista \& Pansarin 1147 (CEN); C. Batista et al. 689 (CEN); D-E. Oliveira 234 (CEN); F-G. Batista 1596 (BHCB); H-I. J.B.F. da Silva 302 (MG); J-K. Plowman et al. 8666 (MG); L-M. J.B.F. da Silva 847 (MG); N. Oliveira \& Gonçalves 284 (CEN)). All figures drawn from dried material. 


\section{Figure $7 \mathrm{H}-\mathrm{K}$}

Selected specimens examined: BRAZIL. AmAPÁ: Santana, 5-V-1982, N.A. Rosa \& M.R. Santos 4316 (HRB, INPA, MG); Amazonas: Rio Negro, Barra, XII1850 III-1851, R. Spruce s.n. (BM32698, K, MG19345, OXF, P, RENZ), Campo de Janauari, s.d., R. Spruce 1298 (K), Campo de Marajózinho, 9-II-1946, A. Ducke 1907 (IAN, MG, RB); Maranhão: Perizes, 6-VII-1954, G.A. Black et al. 54-16540 (IAN); Mato Grosso: São Felix do Araguaia, 14-III-1997, V.C. Souza et al. 14055 (ESA), Luciara, 19-III-1997, V.C. Souza et al. 14593 (ESA); PARÁ: Ilha de Marajó, 9-V-1924, J.G. Kuhlmann 2146 (RB, SP), Ourém, 1-V-1994, J.B.F. da Silva 302 (MG), Conceição do Araguaia, 10-II-1980, T. Plowman et al. 8666 (MG), Muaná, 25-IV-1982, M. Dantas \& Nivaldo S. 1195 (IAN); Roraima: Amajari, Ilha de Maracá, 8-VIII-2003, A.S.F. Castro 1443 (EAC).

Distribution: Brazil (AM, AP, GO, MA, MT, PA, RR, TO), French Guiana, Surinam, and Venezuela.

Illustrations: Pabst \& Dungs (1975, Figure 23, as H. macilenta), Snuverink \& Westra (1983, Figure 12), Renz (1992, Plate 3a), Silva \& Silva (2004, p.250, as H. allemanii and H. leaoana, p.254, as Habenaria sp.), Chiron \& Bellone (2005, p.66, as H. leaoana).

This species has been considered a subspecific taxon of $H$. pratensis. However the differences between $H$. pratensis var. parviflora and $H$. pratensis are greater than the differences between $H$. pratensis and $H$. glazioviana, which are considered distinct species. Thus, as a matter of coherence, $H$. pratensis var. parviflora should also deserve a specific status. An alternative to reduce $H$. glazioviana to a subespecific taxon of $H$. pratensis would require a new combination that we prefer to avoid until a more detailed analysis of the three taxa is undertaken. Analysis of the literature revealed that the earlier available name for this taxon is $H$. spathulifera. Diagnostic characters of $H$. spathulifera are the short pedicellate ovary (1.6-2.5 cm long) and bright yellow flowers, while $H$. pratensis and $H$. glazioviana have long pedicellate ovaries (3-4.7 cm long) and larger, pale yellow flowers. Sepals of $H$. spathulifera are green and the petal and lip bright yellow. The species is typical of seasonally humid places.

36. Habenaria sprucei Cogn. in Mart., Fl. Bras. 3(4):40. 1893. Type: BRAZIL. AmazonAs: Campo de Janauari, s.d., R. Spruce 1221 (Isotypes K, P; photocopy, drawing and fragment of isotype RENZ).

$=$ Habenaria leaoana Schltr., Bot. Centralbl. Beih. 42(2):72. 1925. Type: BRAZIL. Roraima: Boa Vista, Rio Branco, VIII-1913, J.G. Kuhlmann 778 (Holotype
B, destroyed; Isotypes AMES, NY, RB, SP; photocopy, drawing and fragment of isotype RENZ).

Figure 7L-N

Selected specimens examined: BRAZIL. AMAPÁ: Macapá, 24-IV-1924, J.G. Kuhlmann 2072 (RB); Amazonas: Rio Negro, Barra, XII-1850 - III-1851, $R$. Spruce s.n. (BM32683, OXF, RENZ, W); MARANHÃO: São Raimundo das Mangabeiras, 18-I-1998, R.S. Oliveira \& E. Gonçalves 284 (CEN); PARÁ: Almeirim, 8-IV-1903, A. Ducke s.n. (RB18730); RoRAIMA: Pacaraima, 24-VI-1999, J.B.F. da Silva 847 (MG), Boa Vista, 17-VII-2002, L.B. Bianchetti 1719a (CEN).

Distribution: Brazil (AM, AP, MA, PA, RR), French Guiana, Guyana, Surinam and Venezuela.

Illustrations: Mansfeld (1930, Tafel 4, Figure 14, type illustration of H. leaoana), Foldats (1969, Figure 18), Snuverink \& Westra (1983, Figure 7, as H. leaoana), Werkhoven (1986, p.141, as H. leprieuri), Renz (1992, plate $1 \mathrm{~b}$, color photo), Chiron \& Bellone (2005, p.66, as H. trifida).

This species is similar to $H$. aff. $n u d a$, but distinct by the characters outlined in the key. The flowers are completely green and the species is typical of seasonally humid grassy fields.

37. Habenaria subfiliformis Cogn., Bull. Soc. Bot. Belg. 43: 272. 1907. Type: PARAGUAY. San-Joaquin prope Caaguazú, XII-1905, E. Hassler 9681a (Holotype BR).

= Habenaria mitomorpha Kraenzl., Kongl. Svenska Vetenskaps. Handl. 46(10):11, Tafel 2, figure 4. 1911. Type: BRAZIL. Mato Grosso: Serra do Tapirapuan, s.d., C.A.M. Lindman 2931 (Isotype S) syn. nov.

= Habenaria rudolfi-schlechteri Hoehne, Bot. Jahrb. Syst. 68: 126, Tafel 9. 1937. Type: BRAZIL. São Paulo: São Bernardo, XII-1911, A.C. Brade 5085 (Holotype HB; Isotype SP).

\section{Figure 8A-C}

Specimens examined: BRAZIL. PARÁ: Marajó, Câmara, 8-VIII-1950, G.A. Black 50-9994 (IAN); RoraIMA: Serra dos Surucucus, 14-II-1969, G.T. Prance et al. 9898 (HB, INPA). SURINAM. PARA: Fransina savanne, 2-VII-1972, M. \& P. Teunissen 1261 (RENZ, U, image seen). VENEZUELA. BolívAR: Gran Sabana, Santa Elena de Uairén, 9-X-2005, J.A.N. Batista 1597 (BHCB, CEN), Piar, 24-XI-1958, O. Renz 9210 (RENZ, image seen).

Distribution: Brazil (DF, GO, MG, MT, PA, PR, RR, SP, TO), Paraguay, Surinam and Venezuela.

This species is similar and can be confused with $H$. leprieuri. In the Herbarium RENZ and $\mathrm{U}$ all the material 
of the species is misidentified as H. leprieuri. Distinctive features of $H$. subfiliformis are the slender and usually taller plants, the narrower lip midlobe $(0.5 \mathrm{~mm}$ in $H$. subfiliformis vs. $1 \mathrm{~mm}$ in $H$. leprieuri) and the shorter spur (5-6.5 mm vs. 8-12 mm). Examination of the isotype of $H$. mitomorpha and holotype of $H$. rudolfi-schlechteri revealed that they are conspecific with $H$. subfiliformis. Flowers are completely green and the species is typical of seasonally humid places. Flowering time throughout most of the species distribution range occurs mainly at the end of the rainy season.

38. Habenaria sylvicultrix Lindl. ex Kraenzl., Bot. Jahrb. Syst. 16: 101. 1892. Type: BRAZIL. AmAzonas: Barra do Rio Negro, s.d., R. Spruce 1262 (Holotype K; Isotype $\mathrm{K}$ ).

Figure 8D-E

Specimens examined: BRAZIL. Amazonas: Rio Negro, 18-XII-1958, W. Rodrigues 736 (HB, INPA), Manaus, Rio Negro, 14-XII-1977, S. Keel \& J. Guedes 378 (INPA), Manaus, Rio Cuieiras, 17-XII-1961, W. Rodrigues \& B. Wilson 3964 (INPA).

Distribution: Brazil (AM).

This species is similar to $H$. longipedicellata, but distinct by the smaller plants (stem $15-38 \mathrm{~cm}$ including the inflorescence vs. $64-97 \mathrm{~cm}$ in $H$. longipedicellata), the linear leaves that are adpressed to the stem (vs. the lanceolate and spreading leaves of $H$. longipedicellata), the usually few flowered inflorescence, (3-11 flowers vs. (3-)12-35 flowers in H. longipedicellata) the larger flowers (dorsal sepal 6-7 x 5-6 mm vs. 4.5-5.5 x 3.5-4.5 mm in H. longipedicellata) and the longer lateral segments of the petals and lip (lateral segments of the lip 10-14 mm long vs. 6-9 mm long in $H$. longipedicellata). Habenaria sylvicultrix is possibly the only Habenaria species restricted to northern Brazil. However, H. dusenii Schltr., known from the centralwest, southeastern and southern regions of Brazil (GO, MG, MT, PR, SP) is remarkably similar and possibly conspecific. We have not seen any collection of $H$. sylvicultrix from Venezuela and the Guianas and the specimens we have seen from these countries identified as $H$. dusenii do not match the typical H. dusenii from southern Brazil.

39. Habenaria trifida Kunth, Nov. gen. sp. 1: 330. 1816. Type: COLOMBIA. inter villam San Miguel et convallem Guachicon prope Almaguer, Humboldt \& Bonpland 2051 (Holotype P).

= Habenaria allemanii Barb. Rodr., Gen. Sp. Orchid. 2: 254. 1882. Type: BRAZIL. Ceará: Tauapé,
1856, F. Allemão 1500 (Holotype R, not located. Original illustration by Barbosa-Rodrigues in Iconographie des Orchidées du Brésil, v.1, tab. 9 RB, copy K; reproduced in Sprunger, 1996. v.1: 62).

= Habenaria duckeana Schltr., Bot. Centralbl. Beih. 42(2):71. 1925. Type: BRAZIL. RoRaIma: Rio Branco, VII-1913, J.G. Kuhlmann 782 (Holotype B, destroyed; Isotypes AMES, RB, SP);

= Habenaria kuhlmannii Schltr., Bot. Centralbl. Beih. 42(2):72. 1925. Type: BRAZIL. RoraIma: Boa Vista, Rio Branco, I-1913, J.G. Kuhlmann 783 (Holotype B, destroyed; Isotypes AMES, HB, RB, SP).

$=$ Habenaria dentirostris Pabst, Arquiv. Bot. Est. S. Paulo 3(3):118, tabs. 29, 36A. 1955. Type: BRAZIL. PARÁ: Alto Tapajós, Vila Nova, 17-I-1952, J.M. Pires 3944 (Holotype IAN).

Figure 8F-G

Selected specimens examined: BRAZIL. AmAPÁ: Macapá, 16-IV-1982, N.A. Rosa et al. 4241 (HRB, INPA, MG); PARÁ: Almeirim, 8-IV-1903, A. Ducke 3434 (BM32721, MG s.n.), Marajó, 11-IV-1927, A. Ducke s.n. (AMES, HB1923, RB19443, SP31805), Vigia, 1-IV1952, G.A. Black et al. 52-14194 (AMES, IAN), Marapanim, 20-VI-1958, J.M. Pires 6772 (IAN), Rio Paru do Oeste, 19-III-1962, D.C. Fittkau s.n. (INPA12823), Matapiquara, 5-IV-1980, G. Davidse et al. 17901 (NY), Maracanã, 6-IV-1980, G. Davidse et al. 17924 (NY).

Distribution: Mexico, Central America, Trinidad and Tobago, and South America from Colombia to northern Argentina.

Illustrations: Mansfeld (1930, Tafel 2, Figure 6, type illustration of $H$. duckeana; Tafel 4, Figure 13, type illustration of $H$. kuhlmannii), Foldats (1969, Figure 25), Pabst \& Dungs (1975, Figures 15, 22), Dunsterville \& Garay (1979, Figure 349), Snuverink \& Westra (1983, Figure 16), Renz (1992, plate 3b), Kenny (1998, p.19), Silva \& Silva (2004, p.249).

As currently understood, $H$. trifida is a highly variable species with a broad distribution, ranging from Mexico to northern Argentina. The size of the flowers and development of the petals lateral segments are particularly variable, but the general morphology of the flowers is well conserved in the species. Though many of the 19 current synonyms of $H$. trifida are unquestionable, it is possible that a more detailed analysis may segregate some as distinct taxa, probably at the subspecific level. The species is more frequent in dry places, but can also grow in seasonally humid areas. The sepals are green and the petals and lip white, cream or white-greenish. The species can colonize man made habitats and sometimes 


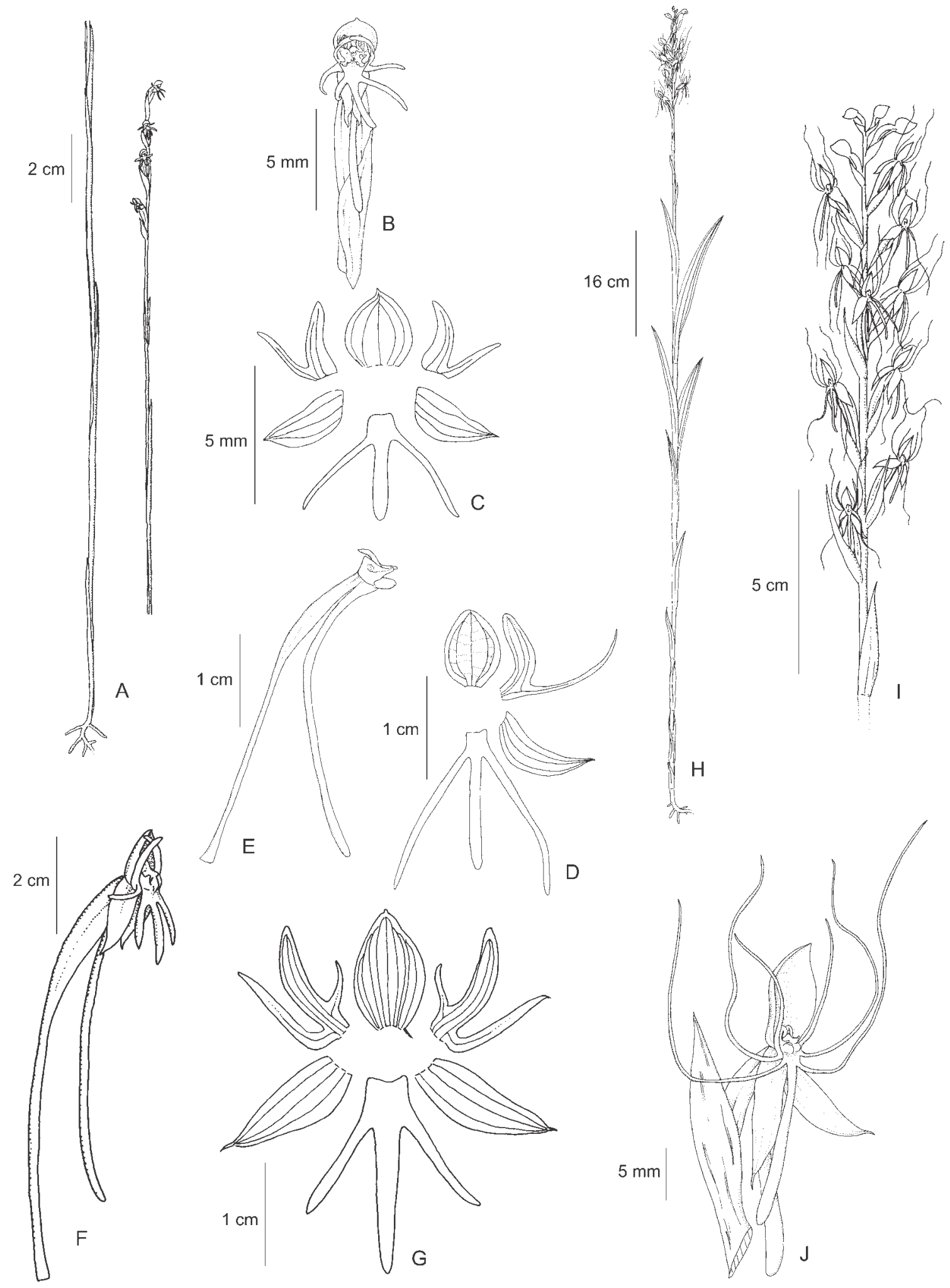

Figure 8. A-C. Habenaria subfiliformis Cogn. A. Habit. B. Flower. C. Perianth. D-E. Habenaria sylvicultrix Lindl. ex Kraenzl. D. Perianth. E. Ovary, column and spur. F-G. Habenaria trifida Kunth. F. Flower. G. Perianth. H-J. Habenaria aff. warmingii Rchb. f. \& Warm. H. Habit. I. Inflorescence. J. Flower. (A-C. Batista 1597 (BHCB); D-E. Rodrigues 736 (INPA); F-G. J.B.F. da Silva 138, without voucher; H-J. Plowman et al. 8649 (MG)). Figures A, C, D, E, H, I and J drawn from dried material, figures $\mathrm{B}, \mathrm{F}$ and $\mathrm{G}$ from alcohol-fixed material. 
it is frequent at road sides, pastures and other disturbed areas. Chosen for illustration here is a flower with tripartite petals, an uncommon characteristic in the species, although its specific name.

40. Habenaria aff. warmingii Rchb. f. \& Warm., Otia Bot. Hamb. 2: 80. 1881. Type: BRAZIL. MinAs Gerais: Lagoa Santa, s.d., J.E.B. Warming 148 (Holotype not located; Holotype drawings by Warming W, photocopy RENZ).

\section{Figure 8H-J}

Specimens examined: BRAZIL. PARÁ: Conceição do Araguaia, 10-II-1980, T. Plowman et al. 8649 (HRB, INPA, MG, NY, RENZ).

The specimens in the collection above are similar to $H$. warmingii, from southeastern Brazil, but distinct by the consistently larger flowers (dorsal sepal 11-13 $\mathrm{x}$ 6-8 mm vs. ca. 7-8 x 5-5.5 mm in $H$. warmingii) and details of the column structure, such as the midlobe of the rostellum that is projected beyond the anthers (vs. enclosed between the anthers in $H$. warmingii). It is possible that they may represent a northern variant of the species.

Doubtfull or obscure species

Habenaria achroantha Schltr., Notizbl. Königl. Bot. Gart. Berlin 54(6):120. 1914. Type: BRAZIL. Rio BrancoGebiet, Serra do Mel, Surumu, 160 m, VII-1909, E. Ule br. 27 (Holotype B, destroyed. No isotype located) n.v.

This species apparently has not been collected after the type specimen and was known only from the type material, which was destroyed at the bombing of the Berlin Herbarium. According to Hoehne (1940) the species is probably conspecific with $H$. repens. In our opinion, based on the original description, the long spur $(3.7 \mathrm{~cm})$ apparently place it close to other taxa characterized by long spurs and conspicuous pedicels such as $H$. longipedicellata and $H$. lehmanniana.

Habenaria schomburgkii Lindl., London J. Bot. 2: 673. 1843. Type: BRAZIL. RorAImA: in swamps on the Rio Branco, VII-1839, R.H. Schomburgk 814 (Holotype K; Isotypes BM, G, OXF, P, US, W; at RENZ photocopies and drawing of the isotypes in $\mathrm{G}, \mathrm{P}, \mathrm{W})$.

Distribution: Brazil (RR), Guyana, Surinam and Venezuela.

Illustrations: Foldats (1969, Figure 31), Dunsterville \& Garay (1979, Figure 347) and Snuverink \& Westra (1983, Figure 14).

The type of this species is a collection from Roraima, but we have not seen any additional material from Brazil that we could undoubtedly assign to H. schomburgkii. Silva \& Silva (2004) have reported the species for the Brazilian Amazon, based on the gathering J.B.F. da Silva $828-\mathrm{MG}$, but which is, in our opinion, referable to $H$. amambayensis. Habenaria schomburgkii is very similar to $H$. amambayensis, but apparently distinct by the lax (vs. densely many-flowered inflorescences in $H$. amambayensis), shorter inflorescences (5-10 cm long in $H$. schomburgkii vs. $15-28 \mathrm{~cm}$ in H. amambayensis) with less flowers (4-13 vs. 15-62 H. amambayensis). Additionally, H. schomburgkii is apparently restricted to the Guiana Shield, while H. amambayensis is distributed from Paraguay to Venezuela. Habenaria schomburgkii has also been recorded for the state of Ceará (Gardner 814 ) in Brazil, but we have not been able to confirm the identification of this collection.

Habenaria ernestii Schltr., Notizbl. Königl. Bot. Gart. Berlin 54(6):122. 1914. Type: GUYANA. campos des Roraima-Gebirges, 1700 m, XII-1909, E. Ule br. 47 (Holotype B, destroyed. No isotype located) n.v.

Specimen examined: VENEZUELA. BolívAR: Gran Sabana, Mount Roraima, 22-VIII-1997, R.S. Oliveira 235 (CEN).

Illustration: Dunsterville \& Garay (1979, Figure 345, as $H$. rodeiensis).

Renz (1992) considered this species related to $H$. gollmeri Schltr., while Foldats (1990) considered it a probable synonym of $H$. roraimensis. On the other hand, Garay \& Romero-González (1998) treated it as a distinct taxon closely related to $H$. rodeiensis and $H$. lehmanniana. The collection Oliveira 235 agrees with Schlechter's original description of $H$. ernestii and Garay and RomeroGonzález (1998) concept of the species. It apparently differs from $H$. lehmaniana by the anterior petal segment that is consistently shorter than the posterior petal segment and the apex of the rostellum which is narrower and not truncate. It is expected that the species occurs and will eventually be colleted in the adjoining state of Roraima in Brazil.

\section{Excluded species}

Habenaria caldensis Kraenzl., fide Pabst \& Dungs (1975), Renz (1992).

We have not seen any material of this species from the Amazon region. The material identified as $H$. caldensis by Pabst, is $H$. sylvicultrix, and the material from the Guianas reported by Renz (1992) and Snuverink \& Westra (1983) is apparently something similar to $H$. candolleana. For more information on the misidentifications of $H$. caldensis see Batista et al. (2004). 
Habenaria culicina Rchb. f. \& Warm., fide Hoehne (1940), Pabst \& Dungs (1975), Ilkiu-Borges \& Cardoso (1996).

The material from the Amazon region identified as this species is referable to $H$. ludibundiciliata.

Habenaria minarum Hoehne \& Schltr., fide Pabst \& Dungs (1975).

This species is a synonym of $H$. rupicola.

Habenaria odontopetala Rchb. f., fide Pabst (1962).

The collection (R.L. Fróes 27836 - IAN 74648) identified as this species by Pabst, author of the report, is referable to $H$. obtusa. Another collection from northern Brazil (J.M. Pires \& N.T. Silva 8058-IAN) also identified as $H$. odontopetala by Pabst is, in our opinion, referable to $H$. dentifera.

Habenaria pratensis (Salzm. ex Lindl.) Rchb. f., fide Cogniaux (1893).

All the material we have seen from northern Brazil from the species pair $H$. pratensis/H. spathullifera is referable to $H$. spathullifera.

Habenaria rupicola Barb. Rodr., fide Silva et al. (1995).

We have not seen any material from the Amazon region that we could assign to this species. The exact identity of $H$. rupicola is not clear, but the species is apparently restricted to southeastern Brazil. A similar species, H. coxipoensis Hoehne, is known from Tocantins and Mato Grosso and may occur in the Amazon region.

Habenaria setacea Lindl., fide Cogniaux (1893), Hoehne (1940), Pabst \& Dungs (1975), Ilkiu-Borges \& Cardoso (1996).

All the material from the Amazon region that we have seen identified as $H$. setacea is referable to $H$. secundiflora.

Habenaria strictissima Rchb. f., fide Ilkiu-Borges \& Cardoso (1996).

This is a very distinct species which has been mistakenly treated as a synonym of $H$. odontopetala by some authors. The species is known from Mexico and Central America.

Acknowledgments - The authors thank the curators of AMES, CEN, EAC, ESA, HB, HRB, HRCB, IAC, IAN, INPA, MBM, MG, NY, OXF, R, RB, SP, SPF and UB for loaning specimens or for providing access to their collections. We also thank Anisio Pedrosa Lima and the "Aliança de
Integração e Desenvolvimento das Comunidades Indígenas de Roraima" for field work support in Pacaraima, Bruno de Campos Souza for logistical support at Boa Vista, Alex Pinheiro de Araújo for the illustrations and Regina C.V.M. da Silva for some of the references. We are also particularly thankful to the following researchers, curators, and herbarium staff for the Habenaria type images used in this work: Victoria Noble (BM), Elmar Robbrecht and Alain V. Velde (BR), Clare Drinkell (K), Wolfgang Lippert and Ingrid Sebeh (M), Thomas Zanoni (NY), Mia Ehn (S), Ernst Vitek and Heimo Rainer (W), Antônio L. V. Toscano de Brito and Cassio van den Berg.

\section{References}

ATZINGEN, N.V., CARDOSO, A.L.R. \& ILKIU-BORGES, A.L. 1996. Flora orquidológica da Serra das Andorinhas, São Geraldo do Araguaia - PA. Boletim do Museu Paraense Emílio Goeldi, série Botânica 12:59-74.

BARBOSA-RODRIGUES, J. 1877. Genera et species orchidearum novarum, v.1. C. \& H. Fleiuss, Rio de Janeiro.

BARBOSA-RODRIGUES, J. 1882. Genera et species orchidearum novarum, v.2. Typographia Nacional, Rio de Janeiro.

BATISTA, J.A.N. \& BIANCHETTI, L.B. 2002. Notes on Habenaria orchiocalcar (Orchidaceae), an overlooked species from central Brazil. Lindleyana 17:115-121.

BATISTA, J.A.N. \& BIANCHETTI, L.B. 2003. Lista atualizada das Orchidaceae do Distrito Federal. Acta Botanica Brasilica 17:183-201.

BATISTA, J.A.N. \& BIANCHETTI, L.B. 2006. The Brazilian Habenaria (Orchidaceae) with hairy segments. Sitientibus, série Ciências Biológicas 6:9-23.

BATISTA, J.A.N., BIANCHETTI, L.B., NOGUEIRA, R.E., PELLIZZARO, K.F. \& FERREIRA, F.E. 2004. The genus Habenaria (Orchidaceae) in the Itacolomi state park, Minas Gerais, Brazil. Sitientibus, série Ciências Biológicas 4:25-36.

BATISTA, J.A.N., BIANCHETTI, L.B. \& MIRANDA, Z.J. G. 2006. A revision of Habenaria section Macroceratitae (Orchidaceae) in Brazil. Brittonia 58:10-41.

CARNEVALI, G., RAMÍREZ-MORILLO, I.M., ROMEROGONZÁLEZ, G.A., VARGAS, C.A. \& FOLDATS, E. 2003. Orchidaceae. In Flora of the Venezuelan Guayana (J.A. Steyermark, P.E. Berry, K. Yatskievych \& B.K. Holst, eds.). Missouri Botanical Garden Press, St. Louis, v.7, p.200-619.

CHIRON, G. \& BELLONE, R. 2005. Les orchidées de Guyane Française. Tropicalia.

COGNIAUX, A. 1893. Orchidaceae. Habenaria. In Flora brasiliensis (C.F.P. Martius, A.G. Eichler \& I. Urban, eds.). F. Fleischer, Munich, v.3, pars 4, p.18-102, tab. 3-18.

DUNSTERVILLE, G.C.K. 1972. Some orchids of Brazil's highest highlands. Bradea 1:83-121. 
DUNSTERVILLE, G.C.K. \& GARAY, L.A. 1979. Orchids of Venezuela, an illustrated field guide. Botanical Museum of Harvard University, Cambridge.

FOLDATS, E. 1969. Orchidaceae. In Flora de Venezuela (T. Lasser, ed.). Instituto Botanico, Caracas, vol.15, parte 1, p.1-502.

FOLDATS, E. 1990. Contribucion a la orquideoflora de Venezuela: Habenaria Willd. BioLlania 7:28-33.

GARAY, L.A. \& ROMERO-GONZÁLEZ, G.A. 1998. Schedulae Orchidum. Harvard Papers in Botany 3: 53-62.

HOEHNE, F.C. 1937. Orchidaceae novae brasilienses. Botanische Jahrbücher 68:126-138 + t.1-25.

HOEHNE, F.C. 1940. Orchidaceas. In Flora brasilica (F.C. Hoehne, ed.). Secretaria da Agricultura, Indústria e Comércio de São Paulo, São Paulo v.12, pars 1, p.1-254, tab.1-153.

ILKIU-BORGES, A.L. \& CARDOSO, A.L.R. 1996. Notas preliminares sobre a flora orquidológica do estado do Pará, Brasil. Boletim do Museu Paraense Emílio Goeldi, série Botânica 12:183-205.

KENNY, J. 1998. Native orchids of the eastern Caribbean. Macmillan Press, London.

KRAENZLIN, F. 1892. Beitrage zu einer Monographie der Gattung Habenaria Willd. Botanische Jahrbücher 16:52-223.

KURZWEIL, H. \& WEBER, A. 1992. Floral morphology of southern African Orchideae. II. Habenariinae. Nordic Journal of Botany 12:39-61.

LINDLEY, J. 1830-1840. The genera and species of Orchidaceous plants. Ridgways, London.

LINDLEY, J. 1843. Contributions towards a Flora of South America: enumeration of plants collected by Mr. Schomburgk in British Guiana. Orchidaceae. Journal of Botany 2:670-674.

MANSFELD, R. 1930. Blütenanalysen neuer Orchideen. 1 - Südamerikanische Orchideen. Repertorium Specierum Novarum Regni Vegetabilis Beihefte 58:1-7 + t.1-60.

PABST, G.F.J. 1955. As orquídeas do herbário do Instituto Agronômico do Norte. Arquivos de Botânica do Estado de São Paulo 3:117-159.

PABST, G.F.J. 1962. As orquideas do herbário do Instituto Agronômico do Norte - II. Arquivos de Botânica do Estado de São Paulo 3:267-271.

PABST, G.F.J. 1967. As orquídeas do território Federal do Amapá. Orquídea 29:258-272.
PABST, G.F.J. \& DUNGS. F. 1975. Orchidaceae Brasilienses, v.1. Kurt Schmersow, Hildesheim.

PIRES J.M. \& PRANCE, G.T. 1985. The vegetation types of the Brazilian Amazon. In Key environments: Amazonia (G.T. Prance \& T.E. Lovejoy, eds.). Pergamon Press, Oxford, p.109-145.

PRIDGEON, A.M., CRIBB, P.J., CHASE, M.W. \& RASMUSSEN, F.N. 2001. Genera orchidacearum, v.2, Orchidoideae, part 1. Oxford University Press, New York.

REICHENBACH, H.G. 1866. Orchideae Warscewiczianae. Beiträge zu einer Orchideenkunde Central-Amerika's. I. Druck von Th.G. Meissner, Hamburg.

RENZ, J. 1992. The genus Habenaria (Orchidaceae) in the Guianas. Candollea 47:483-512.

SCHLECHTER, R. 1914. R. Pilger: Plantae Uleanae novae vel minus cognitae. Orchidaceae. Notizblatt des Königl. Botanischen Gartens und Museums zu Berlin-Dahlem 54:120-122.

SCHLECHTER, R. 1925a. Beitrage zur Orchideenkunde des Amazonas-Gebietes. I. Orchidaceae Kuhlmannianae. Botanischen Centralblatt Beihefte 42:69-82.

SCHLECHTER, R. 1925b. Beitrage zur Orchideenkunde des Amazonas-Gebietes. II. Orchidaceae Huebnerianae: Botanischen Centralblatt Beihefte 42:83-150.

SILVA, M.F.F. \& SILVA, J.B.F. 2004. Orquídeas nativas da Amazônia Brasileira II. Universidade Federal Rural da Amazônia / Museu Paraense Emílio Goeldi, Belém.

SILVA, M.F.F., SILVA, J.B.F., ROCHA, A.E.S., OLIVEIRA, F.P. M., GONÇALVES, L.S.B., SILVA, M.F. \& QUEIROZ, O. H.A. 1995. Inventário da família Orchidaceae na Amazônia brasileira, parte I. Acta Botanica Brasilica 9:163-175.

SILVEIRA, E.C., CARDOSO, A.L.R., ILKIU-BORGES, A.L. \& ATZINGEN, N.V. 1995. Flora orquidológica da Serra dos Carajás, Estado do Pará. Boletim do Museu Paraense Emílio Goeldi série Botânica 11:75-87.

SNUVERINK, J.H. \& WESTRA, L.Y.TH. 1983. Studies on the flora of the Guianas. 3. A survey of Habenaria Willd. in Suriname (Orchidaceae). Proceedings of the Koninklijke Nederlandse Akademie van Wetenchappen, series C 86:567-594.

SPRUNGER, S. (ed.) 1996. João Barbosa Rodrigues Iconographie des Orchidées du Brésil, v.1. Friedrich Reinhardt Verlag, Basle.

WERKHOVEN, M.C.M. 1986. Orchids of Suriname.Vaco Uitgeversmaatschappij, Paramaribo. 